\title{
The Future Path To China's Poverty Reduction-Dynamic Decomposition Analysis With The Evolution Of China's Poverty Reduction Policies
}

\author{
Yingfeng Fang ${ }^{1}$ (D) Fen Zhang ${ }^{2}$
}

Accepted: 11 May 2021 / Published online: 18 May 2021

(c) The Author(s), under exclusive licence to Springer Nature B.V. 2021

\begin{abstract}
The paper uses the Shapley method to decompose poverty changes by income source and growth-distribution-cost according to the history of China's poverty elimination policies in the last forty years. The analysis shows that economic growth contributed to most of the reduction in all periods. Increasing inequality has adverse effects on poverty elimination in that it makes people vulnerable to poverty, which bodes ill for future poverty alleviation. Wages explain most of poverty change for both the urban and rural areas in recent years and are the main reason for increasing inequality in rural areas. Agricultural income played a significant role in reducing rural poverty and inequality in early periods when China experienced many agricultural reforms. In the future, pro-poor growth, reducing inequality and building a relatively integrated urban-rural poverty alleviation system will be most important jobs for China's poverty reduction.
\end{abstract}

Keywords Poverty reduction · Shapley decomposition · Economic growth · Income distribution

\section{Introduction}

With the rapid development of the economy, China has made great achievements in poverty reduction. According to the measurement of the World Bank of $\$ 1.90$ a day (2011 PPP), China's poverty headcount ratio declined from $66.6 \%$ in 1990 to $0.7 \%$ in 2015 , which contributed to $70 \%$ of the poverty reduction worldwide. According to China's official measurement, rural poverty in the country declined from $17.2 \%$ in 2010 to $0.6 \%$ in 2019 , based on the new poverty line of 2300 RMB per year (2010 constant prices) set in 2012 . For China, the year 2020 was an important time point for poverty reduction. In the Outline for Development-oriented Poverty Reduction for China's Rural Areas (2011-2020), China

Yingfeng Fang

eco_yingfeng@whu.edu.cn

1 School of Economics and Management, Wuhan University, NO.299, Bayi Road, Wuchan, Wuhan 430072, China

2 School of Economics and Management, Wuhan University, Wuhan 430072, China 
aimed to make food and clothing affordable and guarantee compulsory education, basic medical services and safe residence to all poor populations. China's President Xi Jinping claimed that "By 2020, the state is committed to ensuring that the rural population living below the current threshold and all impoverished counties are all lifted out of poverty and to solve the problems of regional poverty".

Since 2015, China has targeted all aspects of poverty reduction. Poverty has been gradually reduced through the relocation of the poor from inhospitable areas, the development of local industries, education and healthcare. Moreover, the government made povertyrelated goals the most important assessment indicator for government officials and required low-level leaders to stay in poor villages and lift them out of poverty. These requirements increase the likelihood of making China achieve poverty reduction goals. Although the novel Coronavirus (COVID-19) outbroke in early 2020 increased some difficulties, it couldn't prevent China to achieve this goal which has a very special meaning for China's development, China still achieved $2.3 \%$ in growth and eliminated all absolute poverty in 2010 poverty standard with China's official statistics. Then, what will be the next step for China's poverty reduction? We aim to answer this question through the decomposition analysis of the history of China's poverty alleviation.

As China has a large poor population and has contributed to most of the world poverty reduction, there are many studies on poverty in China, which mainly focus on poverty measurement and poverty dynamics (Jalan \& Ravallion, 1998; Chen \& Ravallion, 2008, 2020; Duclos et al., 2010; Glauben et al., 2012; Yu, 2013; Ward, 2016; Wang \& Zhao 2020). Although these studies described poverty in China, few explained the dynamic causes of China's poverty change. In our paper, we use the Shapely decomposition method proposed by Shorrocks (2013) and Azevedo et al. (2012) to decompose China's poverty change (not poverty) by growth-distribution-cost and income sources.

The method for decomposing poverty dynamics by growth-distribution was first introduced by Dat and Ravallion (1992), but their method was not able to achieve complete decomposition, and there was a residual. Kolenikov and Shorrocks (2005) used the Shapley method to completely decompose poverty into three parts: growth effect, distribution effect and poverty line effect. Based on Kolenikov and Shorrocks (2005), we decompose China's poverty dynamics into three components according to the transition of China's poverty reduction policies over a long period. Moreover, we also decompose the poverty dynamics by income source using the Shapley method, which was introduced by Azevedo et al. (2012), and measure poverty dynamics from a multidimensional perspective, decomposing poverty by group in different levels.

China's poverty reduction policies were conducted from "faces" to "points", which went through counties, villages and households. According to China Health and Nutrition Survey (CHNS), we divided this period into 4 periods, 1989-1993, 1993-2000, 2000-2011, and 2011-2015, according to the history of Chinese poverty reduction since 1986. We found different patterns of poverty reduction in China in these four periods. Economic growth played an important role in poverty reduction for all periods, inequality and macroeconomic fluctuation had adverse effects on poverty reduction. However, because of the continuing increase in inequality in China, the speed of poverty reduction decreased over time. In the period 2011-2015, the adverse effect of distribution increased to outweigh the growth effect in rural China, and this adverse effect was mainly because inequality increases the vulnerability to poverty. This means that in the future, extending the benefits of growth to the poor will be still a very important part of poverty reduction, even when we use relative poverty measurements. Although many studies have used the similar method to decompose poverty change into these two parts, growth and inequality (Yao, 1999; 


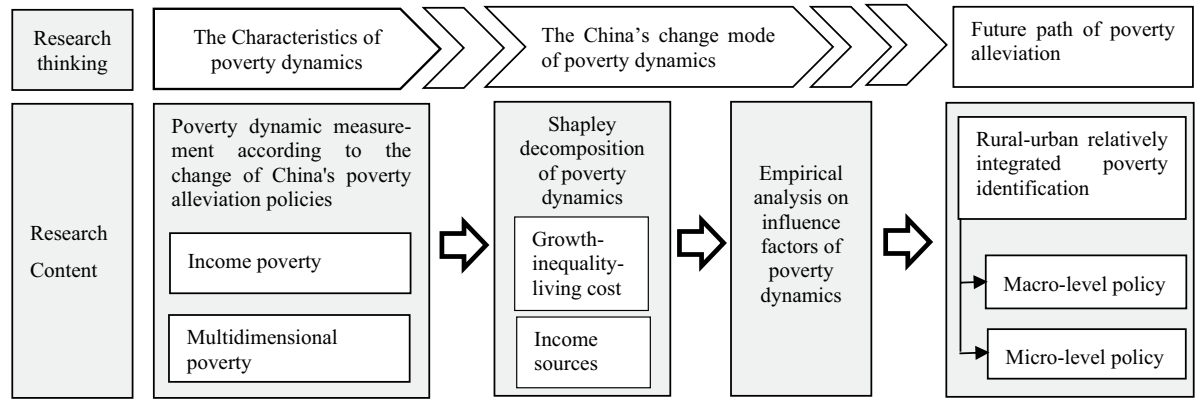

Fig. 1 The technology roadmap of the paper

Ravallion, 2005; Zhang \& Wan, 2006; Toyin \& Timonthy, 2014; Weide \& Milanovic, 2018), they did not analyze the dynamic perspective to determine how these two forces change in different development phases and where this inequality comes from. And they also didn't consider the effect of macroeconomic fluctuation which was measured from the difference of living cost in community level.

What's more, our paper also measured the dynamic poverty effect of different income sources with Shapley decomposition, which could provide us the sources of inequality and growth effect, and also could show us the effect of traditional transfer, agricultural reform and rural-urban flow. Some of the researches have considered decomposition of poverty in income sources (Adigun et al., 2015; Chen et al., 2021), but not decomposition of poverty change. We find that, income from the labor market accounts for most household income in both rural and urban areas. In rural areas, the increase in agricultural income had a significant effect on poverty reduction in the early period when China implemented a series of reforms in agriculture, including the elimination of agricultural tax and increased agricultural subsidy. As the rural-urban flow increases, wages become the main rural income source as well as the reason for increasing rural inequality. All these are seldom studied which can provide some useful thoughts to future poverty reduction policies.

The technology roadmap of paper is shown in the Fig. 1, and the paper is organized as follows. Section 2 describes the course of China's poverty reduction. Section 3 describes the Shapley decomposition method, gives a brief introduction of data, and describes the China's poverty dynamics in multi-dimensions and different groups and then presents the Shapley decomposition outcomes on China's poverty dynamics, and documents poverty transition. Section 4 concludes by discussing China's solution to further poverty reduction.

\section{The Evolution of China's Rural Poverty Reduction Policy}

\subsection{The Start of Poverty Alleviation (Period Before 1993)}

From the founding of the People's Republic of China in 1949 until the early of reform and opening up, China did not put forward any specific poverty reduction strategies, and poverty reduction depended mainly on the increase in income due to economic growth, supplemented by some government relief. In the early period of China's reform and opening up, institutional reform in rural China centered on the household responsibility system, which 
allowed farmers to use and manage the land and arrange their own labor and investment and encouraged them to invest, produce and improve production efficiency (Zhu, 2012). In addition, China's government raised the prices of agricultural products and improved the conditions of agricultural trade and peasants' income. From 1978 to 1985, China's rural economy maintained a high growth rate, with farmers' per capita income increasing by $132 \% .{ }^{1}$ Lin (1992) showed that decollectivization improved China's total factor productivity and accounted for approximately half of the output growth during 1978-1984, and the adjustment in state procurement prices contributed positively to output growth, mainly through the responding input use.

However, in later phases of the market economy reform in China, economic growth no longer automatically reduced rural poverty but rather increased the absolute income gap across regions and rural households. Therefore, in the middle of the 1980s, the Chinese government started the development-oriented poverty reduction program in rural areas in an organized and planned way. In May 1986, the State Council Leading Group of Poor Regions for Economic Development was founded, which was renamed the State Council Leading Group Office of Poverty Alleviation and Development at the end of 1993. China's rural poor population declined from 131 million in 1986 to 80 million in 1993 (according to the official poverty standard in 1978 prices). In this phase, China reduced poverty by improving the economic growth of poor regions through regional development-oriented poverty reduction policies. In 1986, the Chinese government identified 331 povertystricken counties ${ }^{2}$ and launched a series of poverty reduction programs, such as work relief, discounted interest loans, and poverty reduction with help from public sectors and developed provinces. However, these policies covered only a small part of China's rural poor population, and they had a large targeting error. Park et al. (2002) redefined the target gap and error to evaluate the effectiveness of the regional targeting in China's large-scale poverty alleviation program begun in 1986 by analyzing a panel data set of all counties in China for the period 1981-1995. They found that political factors had affected the targeting, and leakage had increased. While the coverage had improved, the allocation of funds among the designated counties was not progressive. However, the program still had a modest effect on the growth of the designated poor counties, increasing the income per capita by $2.28 \%$ per year during $1985-1992$.

Moreover, from the mid-1980s to the early 1990s, China's government formulated and implemented the strategy that pushed the development of coastal areas and allocated investment and other resources to the eastern coastal areas in priority. These macroeconomic and industrial policies did not favor poverty reduction in this period, and the speed of poverty reduction was very slow. Especially from 1985 to 1995, according to the estimation of the World Bank, China's rural poor population unexpectedly increased by approximately 7 million. ${ }^{3}$ In addition, compared to the period $1978-1985$, the growth rate of agricultural add-value per capita declined from $9.7 \%$ to $3.4 \%$, and the growth rate of peasant income per capita declined from $12.2 \%$ to $2 \%$ (Wang, 2007). In this period, the income

\footnotetext{
${ }^{1}$ Poverty monitoring report of rural China, page 50.

2 The standard for identifying poor counties in 1986 was based on the peasants' net income per capita in 1985: 150 yuan for agricultural counties, 200 yuan for husbandry counties, and 300 yuan for old revolutionary base areas.

3 The review of practice on anti-poverty and policy evaluation, in Household Survey Department of the National Bureau of Statistics, 2000, Poverty monitoring report for rural China. Beijing, China: China Statistics Press.
} 


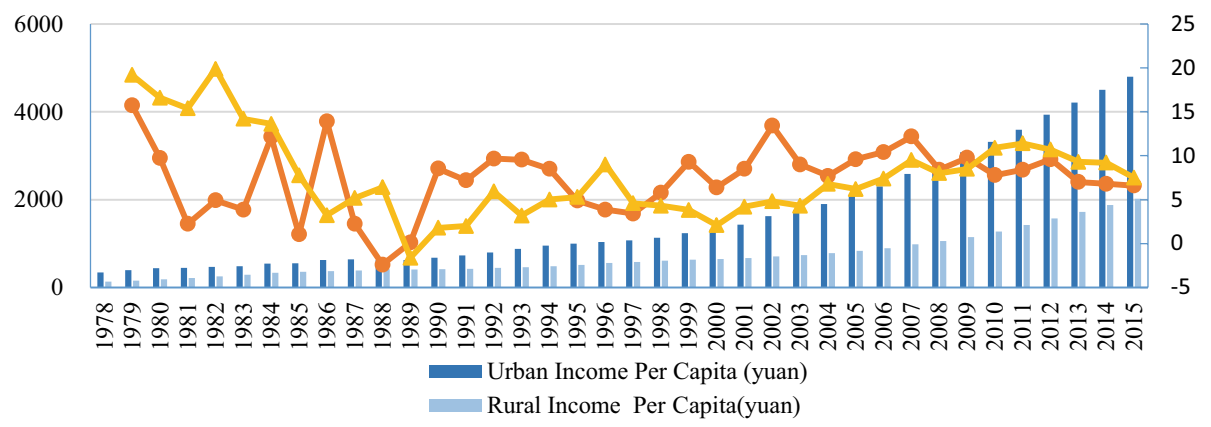

Fig. 2 Per captia real income and its growth for urban and rural households. Data Sources China Statistical Abstract 2016 \& China Compendium of Statistics 1949-2008. Note: real income means the income and its growth rate are calculated at 1978 prices

growth gap between urban areas and rural areas grew (Fig. 2). The gap between eastern and western areas was growing, and the poor population concentrated in the central and western areas of China.

\subsection{8-7 Poverty Relief Program (1994-2000)}

Under the strategy of regional poverty reduction, in 1994, the Chinese government carried out the Seven-Year Priority Poverty Alleviation Program (1994-2000), which aimed to lift 80 million people out of absolute poverty from 1994 to 2000 (referred to hereafter as the 8-7 Program). In addition, the poor counties were adjusted according to the following rule: the counties whose average net rural income was over $700 \mathrm{RMB}$ were removed from the list of poor counties, and those whose average net rural income was less than $400 \mathrm{RMB}$ would be listed among the poor counties. Finally, 592 poor counties were chosen. At this time, China's development-oriented poverty relief work began to tackle key problems. In the period of the 8-7 Program, the Chinese government began to implement a compulsory education project in the poor regions in 1995 and to pilot microfinance programs in 1996. The 8-7 Program mainly focused on developing agriculture and manufacturing attached to agriculture, promoting township enterprises which are resource-exploration and laborintensive, encouraging the organized and planned export of labor services, and implementing the out-migration of poor populations in areas unsuitable for living and hard to exploit.

The 8-7 Program played an important role in pushing the economic development of poor regions and improving the progress of China's poverty reduction. In this period, China's poor population declined from 80 million in 1993 to 32 million in 2000 (according to the official poverty line in 1978 prices, shown in Fig. 3), declined by an average of $12.3 \%$ per year and was 3.6\% higher than the average reduction speed from 1978 to 1993 . China's poor population also declined according to the 1 dollar standard from 266 to 111 million, with an average of $11.7 \%$ every year. For the national poor counties, the added value of agriculture increased by $7.5 \%$ every year, on average, an increase higher than the national economic growth, which was 7\%. The net income per peasant increased from 648 to 1337 RMB (Wang et al., 2004). Meng (2013) also evaluated the impact of the 8-7 Program on rural income growth at the county level from 1994 to 2000 by employing a regression discontinuity approach and found that it resulted in an increase of approximately $38 \%$ in rural income for the treated counties between 1994 and 2000. However, Lu (2015) found no 


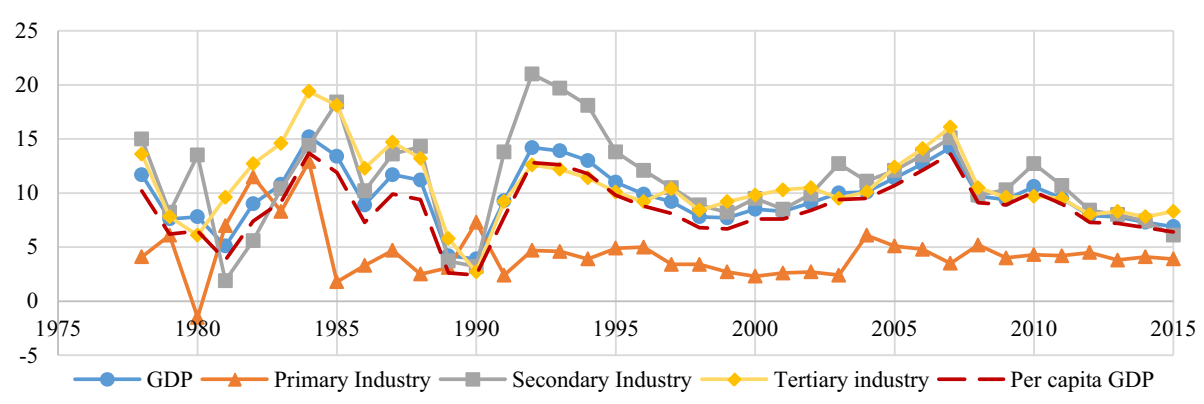

Fig. 3 The growth rate of GDP, per capita GDP, primary industry, secondary industry and tertiary industry. Data Sources China statistical Yearbook 2016. Note: Data in this figure are calculated at constant prices

systematic evidence that counties benefiting from the program enhanced local education spending and observed no short-term or long-term impacts on illiteracy reduction due to Chinese officials' promotion incentives. Qin and Chong (2018) also found that the program failed to improve the infrastructure and sanitary conditions in period 2000-2010. On the one hand, the poor counties could acquire large transfers and some policy support, so many counties lobbied for the privilege of being poor counties, which led to a targeting error (Qin \& Chong, 2018). On the other hand, because of the promotion incentive and regional competition, the local government preferred to invest in production capital, which was beneficial to economic growth ( $\mathrm{Li} \& \mathrm{Zhou}, 2005$; Xu, 2011), but not in human capital, which was more helpful for the poor and had long-run benefits, such as education and health.

Ravallion and Chen (2007) conducted a comprehensive analysis on China's progress in poverty alleviation in this period. Their research showed that, rural economic growth was far more important to national poverty reduction than urban economic growth, agriculture played a far more important role than the secondary or tertiary sectors, the taxation of farmers and inflation hurt the poor, local government spending helped the poor in absolute terms, external trade had little short-term impact, and provinces starting with relatively high inequality saw slower progress against poverty. Montalvo and Ravallion (2010) provided further evidence that the primary sector (mainly agriculture) was the main driving force in China's rural poverty reduction. However, the other sectors contributed most to China's aggregate growth. The development of agriculture, villages and peasant households became a major problem at the end of the 1990s and early 2000s, and this affected China's rural poverty reduction.

\subsection{The Poverty Alleviation Plan for the First Decade (2001-2011)}

In 2001, the State Council of China released the Outline for Development-oriented Poverty Reduction for China's Rural Areas (2011-2020), which is a milestone for a new phase in China's poverty reduction. The targets for poverty reduction changed from poor counties to impoverished villages. In this period, poverty alleviation was advanced for whole villages through labor force training and public sector assistance. Key aims of the plan for the poverty alleviation of 148,000 impoverished villages included providing adequate food and clothing for all poor populations, improving village development, and constructing mechanisms for the sustainable development of the impoverished villages. China's government amended the list of poor counties by removing all poor counties in coastal developed 


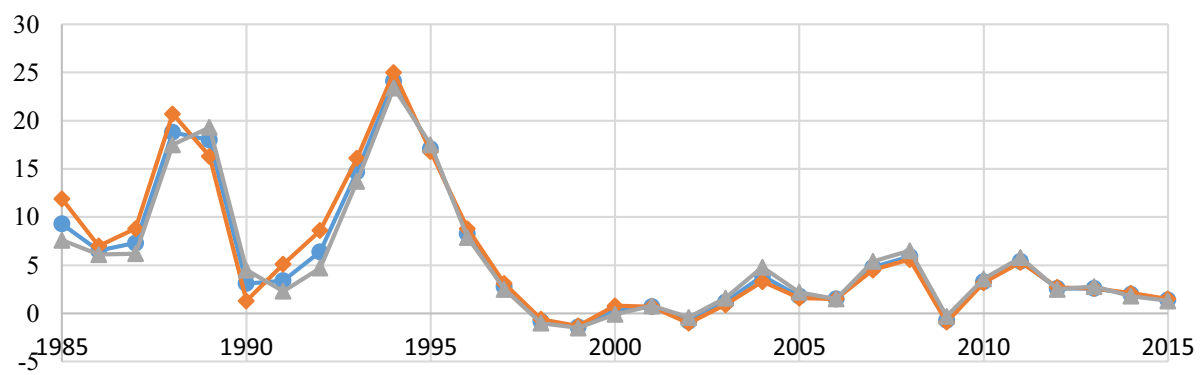

$\multimap$ CPI $\multimap$ urban CPI $\longrightarrow$ rural CPI

Fig. 4 The fluctuation of CPI in China (1985-2015). Data Sources China statistical Yearbook 2016

provinces and increasing the number of poor counties in central and western China. The total number of 592 counties was unchanged, and they were renamed key counties for poverty alleviation and development. To focus on the poor populations in contiguous poor areas, the Chinese government gave the priority of development support to the revolutionary base areas, areas with concentrations of ethnic minorities, border areas, and areas with relatively high incidence of poverty. In addition, the poverty alleviation and development strategy was combined with the western development strategy, which was implemented in 2001 to push the development of poor regions.

In 2003, China's government began to establish the Rural Minimum Living Security System (Dibao), a cash transfer scheme aimed at helping rural residents whose income was below the subsistence level. Before 2006, most of the provinces that had established this system were developed provinces. In 2007, the State Council of China launched a notice on the establishment of the Rural Minimum Living Security System nationwide. By the end of 2016, 22 provinces had established this system, and the 11 provinces that had not were all located in the central and western areas of China. However, while this subsistence allowance benefited the poor recipients, it did not reduce China's overall poverty by much, and it entailed large inclusionary and exclusionary targeting errors (Golan et al., 2017; Westmore, 2018). According to Gao et al. (2010, 2014), the Urban Minimum Living Security System also had large targeting errors, and urban families receiving the subsistence allowance prioritized human capital investment (i.e., education and health) rather than daily necessities (e.g., food, clothing, rent, and utilities).

The New Rural Cooperative Medical System was piloted in 2003, accelerated in 2006 and anticipated nationwide in 2010. In the late 1990s and early 2000s, the problems associated with agriculture, peasants and villages were aggravated and received the attention of China's Central Government. In 2004, China's State Council began to pilot the reduction or elimination of agricultural taxes. In 2006, China eliminated the agricultural tax that had existed for thousands of years. As Fig. 4 shows, China's agricultural growth rate declined from 5\% in 1997 to $2.4 \%$ in 2003 and then increased to $6.1 \%$ in 2004 . However, in later years, the growth rate declined slightly, and it always fluctuated around $4 \%$. This implied that the development of agriculture played an important role in rural poverty reduction.

Park and Wang (2010) conducted an evaluation of China's community-based development program beginning in 2001, which financed public investments in designated poor villages based on participatory village planning. They found that the program significantly increased both government- and village-financed investments, but the targeting efficiency 


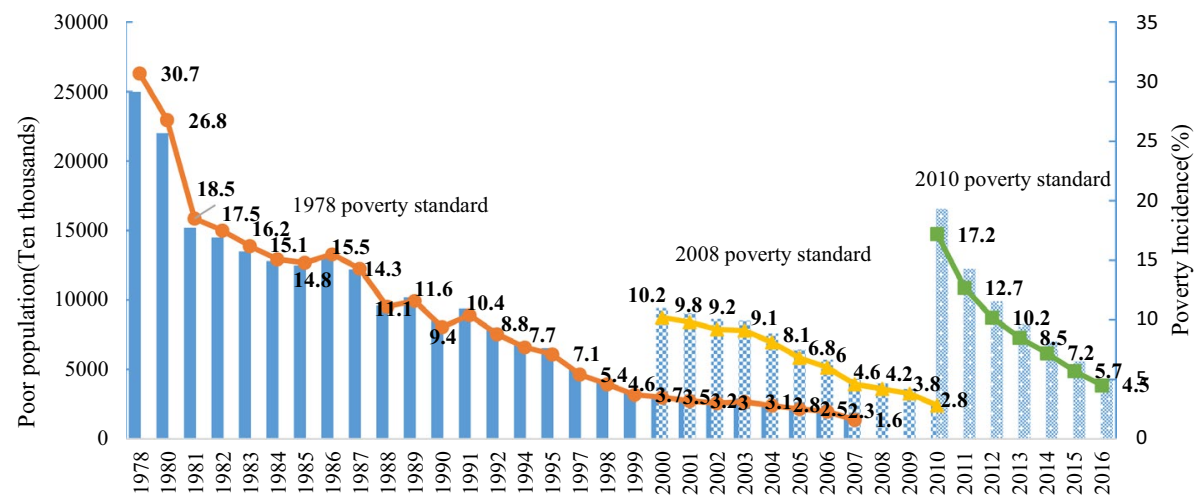

Fig. 5 China's rural poverty from 1978 to 2016. Data sources Poverty monitoring report for rural China 2017. Note: Since 1978, China has adopted three different national poverty standards: the "1978 poverty standard", "2008 poverty standard", and "2010 poverty standard". The "1978 poverty standard" is 100 yuan per person per year at 1978 prices, and it is based on the minimum subsistence standard, which can guarantee people's demand for $2100 \mathrm{cal}$ and some other necessities each day, with the food expenditure accounting for $85 \%$. The "2008 poverty standard" is 865 yuan per person per year at 2000 prices; it was adopted in 2008 and actually used beginning in 2000 . This poverty line reduces the proportion of food expenditure to $60 \%$. In 2012, China's government raised the poverty standard on a large scale to 2300 yuan per person every year (constant prices in 2010); we call this the "2010 poverty standard". Under this poverty standard, the poverty line is 2536 yuan per person per year in 2011. According to the World Bank, PPP 1\$=3.696; thus, China's official poverty line is 2.3 dollars per day, which is 1.21 times the international poverty standard of 1.9 dollars per day

of this poor village-based program was not very high. The program did not increase the income or consumption of poorer households, but it did increase the income and consumption of richer households by 6.1 to $9.2 \%$ from 2001 to 2004. Park and Wang (2010) also found suggestive evidence that governance matters in the distribution of program benefits. Relative gains were greater for richer households in villages with more educated leaders, and higher quality village committees delivered greater benefits to both richer and poorer households. In these ten years, China achieved significant progress in rural poverty reduction. As Fig. 5 shows, China's poor population declined from 94.22 million in 2000 to 26.88 million in 2010 according to China's official poverty standard of 2008. Li (2014) showed that economic growth contributed most to rural poverty reduction in this period, but it was increasingly offset by the inequality effect on poverty reduction, and the poverty alleviation policies were effective but not efficient.

\subsection{The Poverty Alleviation Plan for the Second Decades and Targeted Poverty Alleviation (2012-)}

To accelerate the development of poor regions, promote common prosperity and achieve the goal of building a well-off society in an all-round way by 2020, the Chinese government formulated another ten-year plan for poverty alleviation: the Outline for Development-oriented Poverty Reduction for China's Rural Areas (2011-2020). The Outline focused mainly on unbalanced regional development, extreme poverty, and intergenerational poverty. In this period, the means of poverty alleviation became diversified, including work relief, employment promotion, resettlement of impoverished populations and support for poverty 
eradication through developing industries with local features. During the Twelfth Five-Year Plan period (2011-2015) period, RMB 122 billion was spent on agricultural infrastructure and specialized funds, and RMB116 billion on forestry infrastructure and specialized funds in contiguous poverty-stricken areas. ${ }^{4}$

When China's President Xi Jinping came to power in 2012, eliminating extreme poverty was listed as an important issue in China's development. Xi put forward targeted measures to lift poor people out of poverty, which were first mentioned in November 2013. In 2015, $\mathrm{Xi}$ stated that for targeted poverty alleviation, the government would "precisely identify the poor, make accurate project arrangements, use funds properly, take household-targeted measures, precisely station poverty-relief officials to the poor villages, and get measurable effects of poverty relief." China's government formally took this viewpoint as the guidance of poverty alleviation and concretized it in poverty reduction policies. All of the Documents NO.1 of the Central Government from 2015 to 2018 emphasized that China should take targeted measures to alleviate and eliminate poverty (Kong, 2018). The CPC Central Committee and the State Council jointly issued the Decision on Winning the Fight Against Poverty at the end of 2015 and defined the overall goals of poverty eradication for the 13th Five-Year Plan period (2016-2020). By 2020, the state is committed to ensuring that the impoverished rural population has stable access to adequate food and clothing, compulsory education, and basic medical services and housing; to ensuring that the rural population living below the current poverty threshold and all impoverished counties are all lifted out of poverty; and to solving the problems of regional poverty.

Because lack of the data, there are few researches to study the effect of poverty alleviation in the period 2016-2020, especially about the strategy of targeted poverty alleviation. Some literatures just focused on some specific poor regions in China (Guo et al., 2019; Liao et al., 2021). But according to China's official statistics, China has achieved a great success in poverty reduction, the incidence of rural poverty declined from $10.2 \%$ to $0.6 \%$, and the poor population declined from 122.38 million to 5.51 million over the period 2012-2019, and finally eliminate all the absolute poverty in 2020 (calculated with the 2010 poverty standard). (Table 1).

\section{The Shapley Method and Data}

\subsection{The Shapley Method}

Consider the poverty indicator

$$
P=\pi(F, z)=P(\mu, L, z)
$$

where $F$ is the distribution function that is fully characterized by its mean $\mu$ and Lorenz curve $L$, and $z$ is the poverty line. The poverty function $\pi(\cdot)$ takes the form adopted from Foster et al. (1984):

$$
P=\int_{-\infty}^{z}\left(\frac{z-x}{z}\right)^{\alpha} d F(x), \alpha \geq 0
$$

\footnotetext{
${ }^{4}$ China's Progress in Poverty Reduction and Human Rights: White paper on China's Progress in Poverty Reduction and Human Rights, 2016.
} 
Table 1 Important dates for China's rural poverty reduction

Year Events

1978 Land reform: household responsibility system

1986 The state council leading group of poor region economic development was founded, renamed the state council leading group office of poverty alleviation and development in 1993

1993 Seven-year priority poverty reduction program (1994-2000), which was designed to lift 80 million people out of absolute poverty in the period of seven years from 1994 to 2000

1997 The state council launched a notice on establishing the Minimum Living Security System (Dibao) for urban residents in China

2001 The outline for the development of China's rural areas (2001-2020)

2003 New rural cooperative medical system was piloted in 2003, accelerated in 2006, and aimed to be carried out nationwide in 2010

2004 The plan for the rise of central China; Nationwide agricultural subsidy piloted from 2002 to 2003

2006 Elimination of agricultural taxes

2007 The state council launched a notice on the establishment of the Rural Minimum Living Security System in China. In fact, the rural subsistence allowance began in 2003, but it was established only in some developed provinces before 2006

2011 The outline for development-oriented poverty reduction for China's rural areas (2011-2020)

2013 Targeted poverty reduction first put forward by Chinese President Xi Jinping at the end of 2013 and taken as the guidance for China's poverty reduction from 2014

2015 The CPC Committee and the State Council jointly issued the Decision on Winning the Fight Against Poverty and defined the overall goals of poverty eradication for the 13 th five-year plan period (2016-2020)

2016 The 13th five-year plan for poverty alleviation through relocation, the guideline on official evaluation for poverty alleviation which required to implement every year from 2016

2018 The guideline on three-year action to win the battle against poverty

2020 Eliminate the absolute poverty in 2010 poverty standard

where $x$ is income. In the following, we call this the FGT index, and FGT0, FGT1, and FGT2 represent $\alpha=0, \alpha=1$, and $\alpha=2$, respectively. When $\alpha=0$, the poverty function will deteriorate to the headcount poverty rate.

\subsection{Three-Way Decomposition of Poverty Dynamics}

Referring to Kolenikov and Shorrocks (2005), when the Shapley decomposition is used, the change in poverty from period 0 to 1 can be decomposed in three ways as follows:

$$
\begin{aligned}
\Delta P= & P_{1}-P_{0} \\
= & P\left(\mu_{1}, L_{1}, z_{1}\right)-P\left(\mu_{0}, L_{0}, z_{0}\right) \\
= & \frac{1}{6}\left\{2 \left[\left(P\left(\mu_{1}, L_{1}, z_{1}\right)-P\left(\mu_{0}, L_{1}, z_{1}\right)\right]+P\left(\mu_{1}, L_{0}, z_{1}\right)-P\left(\mu_{0}, L_{0}, z_{1}\right)\right.\right. \\
& \left.\quad+P\left(\mu_{1}, L_{1}, z_{0}\right)-P\left(\mu_{0}, L_{1}, z_{0}\right)+2\left[P\left(\mu_{1}, L_{0}, z_{0}\right)-P\left(\mu_{0}, L_{0}, z_{0}\right)\right]\right\} \quad \text { (growth effect) } \\
+ & \frac{1}{6}\left\{2 \left[\left(P\left(\mu_{1}, L_{1}, z_{1}\right)-P\left(\mu_{1}, L_{0}, z_{1}\right)\right]+P\left(\mu_{1}, L_{1}, z_{0}\right)-P\left(\mu_{1}, L_{0}, z_{0}\right)\right.\right. \\
& \left.\quad+P\left(\mu_{0}, L_{1}, z_{1}\right)-P\left(\mu_{0}, L_{0}, z_{1}\right)+2\left[P\left(\mu_{0}, L_{1}, z_{0}\right)-P\left(\mu_{0}, L_{0}, z_{0}\right)\right]\right\} \text { (distributional component) } \\
& +\frac{1}{6}\left\{2 \left[\left(P\left(\mu_{1}, L_{1}, z_{1}\right)-P\left(\mu_{1}, L_{1}, z_{0}\right)\right]+P\left(\mu_{0}, L_{1}, z_{1}\right)-P\left(\mu_{0}, L_{1}, z_{0}\right)\right.\right.
\end{aligned}
$$


Table 2 Proposed methodology along one possible path

\begin{tabular}{ll}
\hline$P=\pi\left(F\left(Y\left(y_{1}, y_{2}, \ldots y_{K}\right)\right), z\right)$ & Poverty in period 1 \\
\hline$\widehat{P_{1}}=\pi\left(F\left(\hat{y}_{1}, y_{2}, \ldots, y_{K}\right), z\right)$ & Contribution of income source 1:P $-\widehat{P_{1}}$ \\
$\widehat{P_{2}}=\pi\left(F\left(\hat{y}_{1}, \hat{y}_{2}, \ldots, y_{K}\right), z\right)$ & Contribution of income source 2: $\widehat{P_{1}}-\widehat{P_{2}}$ \\
$\ldots$ & $\ldots$ \\
$\widehat{P_{K}}=\pi\left(F\left(\hat{y}_{1}, \hat{y}_{2}, \ldots, \hat{y}_{K}\right), z\right)$ & Contribution of income source K: $\widehat{P_{K-1}}-\widehat{P_{K}}$ \\
\hline
\end{tabular}

There are three components of the decomposition of poverty change: the growth effect, distributional component and poverty line, where the poverty line reflects the effects of changes in living cost, and further implies the poverty effect of macroeconomic fluctuation.

\subsection{Decomposition by Income Sources}

Considering that there are $\mathrm{K}$ types of income sources, $y_{1}, y_{2}, \ldots y_{K}$. Hence, the poverty function can be rewritten as follows:

$$
P=\pi\left(F\left(Y\left(y_{1}, y_{2}, \ldots y_{K}\right)\right), z\right)
$$

We decomposed the poverty change with the nonparametric Shapley decomposition method proposed by Azevedo et al. (2012), and Rani and Furrer (2016). The technical program was obtained from Azevedo et al. (2012). Since the distribution of household income and its different sources for periods 0 and 1 are known, counterfactual distributions for period 1 can be generated by substituting the observed level of a given income source $y_{k}$ by its observed level for period $0, \hat{y}_{k}$. For each counterfactual distribution, the poverty measure is calculated, and these counterfactuals can be interpreted as the level of poverty that would have prevailed in the absence of change in that given income source.

For instance, to evaluate the impact of the change in the distribution of income source 1 , we compute $\widehat{P_{1}}$, where the value for $y_{1}$ is substituted by its value in period $0, \hat{y}_{1}$ :

$$
\widehat{P_{1}}=\pi\left(F\left(\hat{y}_{1}, y_{2}, \ldots, y_{K}\right), z\right)
$$

The effect of the change in income source 1 can then be calculated as $P-\widehat{P_{1}}$. Similarly, the contribution of each income component to the change in total income poverty can be computed as shown in Table 2. The computation suggested in Table 2 is path dependent, and the effect of an income source depends on the ordering of sources. With $K$ income sources, there are $K$ ! potential decomposition paths. We calculate the decomposition across all possible paths and then take the average between them following the method proposed by Azevedo et al. (2012). The average effect for each variable is also known as the Shapley-Shorrocks estimate of each component, and the final contribution of the component $y_{i}$ is determined by the following weighted average:

$$
C_{i}=\sum_{m=0}^{K-1} \sum_{Y} \frac{m !(K-m-1) !}{K !}\left[P\left(\pi\left(y_{i}, Y_{K-1, m+1}-\left\{y_{i}\right\}\right)\right)-P\left(\pi\left(\hat{y}_{i}, Y_{K-1, m}-\left\{y_{i}\right\}\right)\right]\right.
$$

where $m$ indicates how many components have already changed from period 0 to period 1 , and $Y$ denote all the combinations of the other $K-1$ components that have already changed from period 0 to period 1 . 


\subsection{Data}

There are a few household surveys in China. The China Health and Nutrition Survey (CHNS) begins in 1989 and is an international collaborative project between the Carolina Population Center at the University of North Carolina at Chapel Hill and the National Institute for Nutrition and Health (former National Institute of Nutrition and Food Safety) at the Chinese Center for Disease Control and Prevention. The CHNS has many advantages. It is a panel data covering a long period, with 10 rounds of surveys conducted in 1989, 1991, 1993, 1997, 2000, 2004, 2006, 2009, 2011, and 2015. It is always used to analyze the dynamics of poverty in China over long periods (Ward, 2016; Goh, et al., 2009; Zhang \& Wan, 2006). The China Health and Retirement Longitudinal Survey (CHARLS) and China Family Panel Studies (CFPS), both launched by institutes of Peking University, also include panel data, but they began after 2010. The Chinese Household Income Project (CHIP) has also conducted five waves of household surveys over a long period in 1989, 1996, 2003, 2008 and 2013, despite it is not panel data.

The CHNS covers nine Chinese provinces that vary substantially in geography and economic development: Liaoning, Heilongjiang, Jiangsu, Shandong, Henan, Hubei, Hunan, Guangxi, and Guizhou. These nine provinces have a strong regional representativeness. Liaoning and Heilongjiang are in the northeast part of China and are representative of the old industrial base of China. Jiangsu and Shandong are in the eastern part and have a highly developed economy, especially since the implementation of the reform and openingup policy. Henan, Hubei and Hunan are located in the central part of China. They are traditional agriculture areas, and in recent years, they have developed rapidly with policy support from the central government, although regions within these provinces still face uneven development. Guangxi and Guizhou are in the southwest part of China, in mountainous areas that have a backward economy. Thus, while not nationally representative, the CHNS provides a good picture of the diverse poverty conditions in different regions of China. Three mega cities (Beijing, Shanghai, Chongqing) have been included in the survey since 2011 and three more provinces (Zhejiang, Shangxi, Yunnan) since 2015. However, these three mega cities are not targets of China's poverty reduction policies and have a small rural poor population, and the data of the three newly added provinces are not yet available on the CHNS website.

A multistage, random cluster process was used to draw the samples surveyed in each of the provinces. Counties in the nine provinces were stratified by income, and a weighted sampling scheme was used to randomly select counties in each province. Villages and townships within the counties and urban and suburban neighborhoods within the cities were selected randomly. From 1989 to 1993, there were 190 primary sampling units: 32 urban neighborhoods, 30 suburban neighborhoods, 32 towns (county capital cities), and 96 rural villages. In 2000, the primary sampling units increased to 216: 36 urban neighborhoods, 36 suburban neighborhoods, 36 towns, and 108 villages. There are approximately 7,200 households in the overall survey, covering over 30,000 individuals. Follow-up levels are high, but families that migrate from one community to another are not followed, while attempts are made to follow movement within the primary sampling units and some larger urban entities. ${ }^{5}$

\footnotetext{
5 The introduction of the sampling procedure is from the CHNS website: http://www.cpc.unc.edu/projects/ china/.
} 
Table 3 China's rural poverty headcount ratio for each indicator in 1989-2015 (\%)

\begin{tabular}{lcccccccccc}
\hline & 1989 & 1991 & 1993 & 1997 & 2000 & 2004 & 2006 & 2009 & 2011 & 2015 \\
\hline Drinking Water & 39.4 & 31.2 & 24.9 & 16.8 & 18.0 & 14.9 & 15.1 & 13.0 & 11.1 & 18.2 \\
Sanitation & 78.1 & 75.3 & 73.8 & 71.1 & 70.0 & 63.9 & 60.7 & 51.6 & 49.6 & 33.3 \\
Electricity & 10.5 & 5.79 & 1.97 & 0.86 & 1.1 & 0.34 & 0.37 & 0.37 & 0.91 & 0.43 \\
Cooking Fuel & 49.8 & 53.8 & 51.8 & 50.2 & 38.7 & 35.0 & 30.3 & 22.6 & 22.5 & 14.5 \\
Asset & 37.4 & 30.2 & 22.8 & 16.7 & 12.6 & 9.01 & 8.25 & 5.91 & 3.54 & 2.16 \\
Years of School & 12.1 & 8.59 & 7.93 & 9.4 & 8.75 & 10.9 & 15.5 & 14.0 & 15.4 & 9.94 \\
Child Attendance & 6.63 & 4.52 & 6.72 & 2.72 & 2.27 & 0.02 & 0.81 & 0.7 & 1.18 & 1.6 \\
Nutrition & 13.02 & 26.78 & 23.73 & 20.82 & 17.32 & 15.22 & 14.51 & 15.53 & 13.32 & - \\
Child Mortality & 2.37 & 0.82 & 0.34 & 0.66 & 0.41 & 0.47 & 0.17 & 0.23 & 0.03 & - \\
Income & 60.58 & 60.09 & 53.13 & 42.62 & 35.88 & 29.70 & 30.10 & 16.15 & 15.35 & 16.30 \\
\hline
\end{tabular}

\subsection{Poverty Dynamics in China}

\subsubsection{Multidimensional Poverty Dynamics}

For a comprehensive understanding of rural poverty in China, we begin with an analysis of the dynamics of rural poverty from a multidimensional perspective, following Alkire \& Foster (2007), Alkire \& Foster (2011) and Alkire \& Fang (2019), where more technique details can be obtained. We consider four dimensions: living standard, education, health and income. First, the dimension of living standard is composed of five indicators: cooking fuel, drinking water, sanitation, electricity and assets. The first three indicators play an important role in health improvement and education improvement (Geruso \& Spears, 2015; Zhang, 2012; Zhang \& Xu 2016; Duflo, et al., 2015); electricity is a basic household necessity, and assets reflect the household living standard. If household cooks with straw, wood, charcoal, then it is in cooking fuel poverty. If it has a cement open pit, earth open pit or no bathroom, then it is considered to be in sanitation poverty. If the source of drinking water is an open well (less than $5 \mathrm{~m}$ ), creek, spring, river, etc., or if safe drinking water is more than a $30 \mathrm{~min}$ walk from home, roundtrip, we consider this household to be in drinking water poverty. As Table 3 shows, the rural poverty incidence of drinking water, sanitation, and cooking fuel were still very serious, especially the incidence of sanitation, still with $33.3 \%$ of rural households lacking clean sanitation facilities in 2015 . The poverty incidence for drinking water declined from $39.4 \%$ in 1989 to $11.1 \%$ in 2011 but then increased to $18.2 \%$ in 2015 . The poverty incidence of cooking fuel declined from $49.8 \%$ in 1989 to $14.5 \%$ in 2015 . The assets considered include the ownership of some durable consumer goods, including television, telephone, refrigerator, electric fan and air conditioner, bicycle, motorbike, car and truck. With technological advancement, some consumer goods, such as television and telephone, have been upgraded; thus, we consider a household to have television if it owns a black/white or color TV and to have a telephone if it owns a telephone or cellphone. Then, we consider the household to be in asset poverty if it does not own 
more than one of the following assets: television, telephone, bicycle, motorcycle, tricycle or refrigerator, and if it does not own a car or a truck. The incidence of asset poverty declined steadily, from $37.4 \%$ in 1989 to $2.16 \%$ in 2015 , which implies that the Chinese living standard improved steadily after the reform and opening up.

Rural education poverty has two parts. First, for the years of schooling, if no household member has completed 5 years of schooling, then we consider this household to be in poverty in terms of years of schooling. The table shows that Chinese education poverty continued to deteriorate from 2000 to 2011, and the poverty incidence for years of schooling increased from $8.75 \%$ to $15.4 \%$ in 2011 . The reason for this phenomenon may be the strong peasant labor flow from rural to urban areas in this period, and the household registration (hukou) system has created a large number of "left-behind" children who had no advantages in the competitive Chinese education system. In addition, most people who had acquired high-level education moved out of the village (Alkire \& Fang, 2019). As the Chinese government began to recognize the seriousness of this problem and release a series of education policies, education poverty declined to $9.4 \%$ in 2015 . Second, concerning child attendance, if school-age children are not in school, we consider this household to be in child attendance poverty. As Table 3 shows, Chinese rural child attendance poverty declined from $6.63 \%$ in 1989 to $0.02 \%$ in 2004 , then slowly rebounded to $1.6 \%$ in 2015 .

We also use two kinds of health indicators to measure health poverty. The first is nutrition, if any adult or child for whom there is nutritional information is malnourished, then we consider the household to be in nutrition poverty. ${ }^{6}$ As Table 3 shows, China's rural population had a higher level of nutrition poverty; although the nutrition poverty incidence declined over time, $13.32 \%$ of the rural population was still affected by nutrition poverty. The second indicator is child mortality, the same poverty standard as that used by Alkire and Fang (2019); that is, if a child died between the survey of this year and the last wave, then we consider this household to be in child mortality poverty. For 1989, we considered the period between 1985 and 1989, so the child mortality poverty was high in 1989 . For the following years, the poverty incidence of child mortality was consistently less than $1 \%$ and continued to decline to $0.03 \%$ in 2011 . These indicators are important means for measuring multidimensional poverty. As these outcomes show, rural poverty in various dimensions was very serious over the considered period. The most important causes of poverty were China's registration system and rural-urban migration. In the early stage, this migration was good for rural poverty elimination, and households near the poverty line were more likely to have a migrant than richer or poorer households (Du et al., 2005). In the last twenty years, most of the rural young people have moved out of the villages, leaving behind the elderly with some of their grandchildren. This deteriorating situation has made rural China much more vulnerable due to the aging problem and harms the development of agriculture. Increasing numbers of people are falling into poverty due to illness and dropping out of school. To persist in eliminating poverty, we need to transfer our focus from income poverty measurement to multidimensional poverty measurement.

\footnotetext{
6 As introduced by Alkire and Fang (2019), the nutrition deprivation standard is as follows: children (0-5 years old) are considered malnourished if their z-scores of weight-for-age are below two standard deviations from the median of the reference population. Children (5-19 years old) are considered malnourished if their Z-scores of BMI-for-age are below two standard deviations from the median of the reference population, while adults are considered malnourished if their BMI is below 18.5.
} 
Table 4 Dynamics of poverty headcount ratio and poverty risk for each group in rural China

\begin{tabular}{|c|c|c|c|c|c|c|c|c|c|c|}
\hline \multirow[t]{2}{*}{ Province } & \multicolumn{5}{|c|}{ Poverty headcount ratio (\%) } & \multicolumn{5}{|c|}{ Poverty risk } \\
\hline & 1989 & 1993 & 2000 & 2011 & 2015 & 1989 & 1993 & 2000 & 2011 & 2015 \\
\hline National & 51.15 & 49.08 & 30.31 & 13.75 & 13.60 & - & - & - & - & - \\
\hline Rural & 60.58 & 55.13 & 35.88 & 15.35 & 16.30 & 1.19 & 1.12 & 1.18 & 1.12 & 1.20 \\
\hline Urban & 32.06 & 35.22 & 18.53 & 10.42 & 7.95 & 0.63 & 0.72 & 0.61 & 0.76 & 0.59 \\
\hline \multicolumn{11}{|c|}{ Decomposition of rural poverty by province } \\
\hline Liaoning & 57.37 & 38.52 & 16.87 & 7.12 & 9.74 & 0.95 & 0.70 & 0.47 & 0.46 & 0.60 \\
\hline Heilongjiang & - & - & 50.96 & 10.54 & 12.75 & - & - & 1.42 & 0.69 & 0.78 \\
\hline Jiangsu & 41.67 & 45.00 & 16.72 & 5.85 & 8.64 & 0.68 & 0.82 & 0.47 & 0.38 & 0.53 \\
\hline Shandong & 50.94 & 45.46 & 26.81 & 14.02 & 20.44 & 0.84 & 0.83 & 0.75 & 0.91 & 1.25 \\
\hline Henan & 72.64 & 74.32 & 55.84 & 39.02 & 29.64 & 1.20 & 1.35 & 1.56 & 2.54 & 1.82 \\
\hline Hubei & 65.51 & 67.57 & 41.12 & 9.60 & 10.63 & 1.08 & 1.23 & 1.15 & 0.62 & 0.65 \\
\hline Hunan & 54.06 & 47.48 & 41.27 & 17.67 & 15.82 & 0.89 & 0.86 & 1.15 & 1.15 & 0.97 \\
\hline Guangxi & 64.80 & 54.98 & 30.66 & 18.23 & 18.34 & 1.07 & 1.00 & 0.86 & 1.19 & 1.13 \\
\hline Guizhou & 76.56 & 66.04 & 44.78 & 15.63 & 21.11 & 1.26 & 1.20 & 1.25 & 1.02 & 1.30 \\
\hline \multicolumn{11}{|c|}{ Characteristics of the household head } \\
\hline Han & 58.04 & 53.76 & 34.70 & 14.98 & 16.14 & 0.94 & 0.97 & 0.97 & 0.98 & 0.99 \\
\hline Minority & 79.21 & 63.23 & 43.10 & 17.32 & 17.37 & 1.29 & 1.15 & 1.20 & 1.13 & 1.06 \\
\hline Male & 61.97 & 60.91 & 36.07 & 13.38 & 15.14 & 1.02 & 1.02 & 1.01 & 0.87 & 0.93 \\
\hline Female & 48.68 & 52.68 & 34.48 & 21.44 & 20.81 & 0.80 & 0.86 & 0.96 & 1.40 & 1.28 \\
\hline Farmer & 70.47 & 67.97 & 45.11 & 16.41 & 14.24 & 1.16 & 1.23 & 1.28 & 1.31 & 1.36 \\
\hline Nonfarmer & 35.27 & 28.34 & 13.59 & 7.14 & 7.78 & 0.58 & 0.51 & 0.39 & 0.57 & 0.74 \\
\hline Never married & 60.47 & 56.52 & 31.32 & 34.62 & 33.33 & 1.00 & 1.02 & 0.87 & 2.28 & 2.05 \\
\hline Married & 60.85 & 54.84 & 35.19 & 13.57 & 15.78 & 1.01 & 0.99 & 0.98 & 0.89 & 0.97 \\
\hline Divorced/Separated & 35.71 & 71.43 & 39.29 & 25.00 & 11.91 & 0.59 & 1.29 & 1.10 & 1.65 & 0.73 \\
\hline Widowed & 57.14 & 59.44 & 43.19 & 21.91 & 19.21 & 0.94 & 1.08 & 1.21 & 1.44 & 1.18 \\
\hline \multicolumn{11}{|c|}{ Dependency of rural household } \\
\hline No children & 52.13 & 49.45 & 33.43 & 14.15 & 15.58 & 0.86 & 0.90 & 0.93 & 0.92 & 0.96 \\
\hline 1 child & 52.14 & 47.21 & 35.10 & 16.03 & 15.09 & 0.86 & 0.86 & 0.99 & 1.04 & 0.93 \\
\hline 2 children & 70.99 & 62.79 & 41.61 & 22.22 & 23.08 & 1.17 & 1.14 & 1.16 & 1.45 & 1.42 \\
\hline 3 children and more & 77.47 & 81.16 & 53.85 & 27.66 & 20.76 & 1.28 & 1.47 & 1.50 & 1.80 & 1.27 \\
\hline No elderly & 59.31 & 53.36 & 32.60 & 13.30 & 14.57 & 0.98 & 0.97 & 0.91 & 0.87 & 0.89 \\
\hline 1 elderly & 67.22 & 61.29 & 44.39 & 22.51 & 18.49 & 1.11 & 1.11 & 1.24 & 1.48 & 1.13 \\
\hline 2 elderly and more & 68.42 & 71.43 & 60.87 & 16.77 & 20.83 & 1.13 & 1.30 & 1.70 & 1.09 & 1.29 \\
\hline
\end{tabular}

poverty risk for subgroup $\mathrm{k}=$ Poverty_Share(k)/Population_share(k). Poverty_share(k) is the contribution of rural poverty of subgroup $\mathrm{k}$ to total rural poverty. Population_share(k) is the rural population share of subgroup $\mathrm{k}$

\subsubsection{Rural Poverty Decomposition by Group}

As Table 4 shows, China has achieved great success in poverty reduction for both rural and urban areas. The poverty headcount ratio declined from $51.15 \%$ in 1989 to $13.60 \%$ in 2015 , where rural poverty headcount ratio declined from $60.58 \%$ in 1989 to $16.30 \%$ in 2015, and the urban poverty headcount ratio declined from $32.06 \%$ in 1989 to $7.95 \%$ in 
2015. Considering the change in rural poverty in different periods, from 1989 to 1993, the poverty headcount ratio declined from $60.58 \%$ to $55.13 \%$, representing a small decline of $5.45 \%$. The most rapid decline occurred in the period from 1993 to 2011 . In the period of the "8-7 Program", from 1993 to 2000, the rural poverty headcount ratio declined from $55.13 \%$ to $35.88 \%$, and in the first "Ten-year poverty reduction plan", from 2000 to 2011 , the poverty headcount ratio continued to decline to $15.35 \%$. In 2011, China began another "ten-year poverty reduction plan" and raised the poverty line to 2300 RMB (2010 price). From the data, we find that the poverty headcount ratio increased from $15.35 \%$ to $16.30 \%$ in 2015, which is much higher than the Fig. 3 according to official statistics. One explanation for this discrepancy is that the income used in the CHNS is net income, which is calculated from gross income deducted by the input cost, and this produces many negative values in the income data. Zhang et al. (2014) used a few household surveys in China to measure poverty, including the CFPS of 2010, the Chinese General Social Survey (CGSS) of 2010, the China Household Finance Survey (CHFS) of 2011, and the CHIP of 2007. They found that the poverty headcount ratio at the national, rural, and urban levels based on the CFPS, CGSS, and CHFS were all much higher than the official estimates and estimates based on the CHIP.

Another very important reason for the higher poverty headcount ratio is that China was also affected by the American financial crisis in 2008, and the economy entered a transformation period, as China's growth rate declined from 9.5\% in 2011 to $7.9 \%$ in 2012. According to official statements, from 2011 to 2015, China's economic development entered a new normal. During this time, China had to simultaneously deal with the slowdown in economic growth, make difficult structural adjustments and absorb the effects of the previous economic stimulus policies. Concerning poverty reduction, China's President Xi Jinping put forward the aim to take targeted measures to help people lift themselves out of poverty at the end of 2013, seeking to eradicate absolute poverty in China before 2020. China began to implement these poverty reduction policies in 2015 . Therefore, we need to wait for a new round of surveys to evaluate the effect of these policies.

Urban poverty is also a serious issue that has recently caught the attention of China's government and economists. In China, because of particularities concerning residence, child education, medical expenditure and employment, urban poverty tends to be severe. In our measurement, the urban poverty incidence was $7.95 \%$ in 2015 , and the urban poverty risk was 0.59 , a value less than 1 , which means that urban poverty was not the main force of poverty in China compared with rural poverty: $1 \%$ of China's urban population could explain only $0.59 \%$ of poverty at the national level. In the same year, the rural poverty risk was 1.20 , which means that $1 \%$ of China's rural population could explain $1.2 \%$ of poverty at the national level. Moreover, in all five years, the rural poverty risk was greater than 1.1, and the urban poverty risk was less than 0.8 .

We also describe the rural poverty dynamics for different groups. First, considered different provinces, Jiangsu Province had the lowest poverty headcount ratio, from $41.67 \%$ in 1989 to $8.64 \%$ in 2015 , as well as the lowest poverty risk, which equals the ratio of the poverty contribution of group $\mathrm{j}$ to the population share of group j. In 2015, the poverty risk of Jiangsu was very low, 0.53 , which means that $1 \%$ of the rural population in Jiangsu accounts for only $0.53 \%$ of the total rural poverty in China. However, the ranks of the other eight provinces changed in different years. In 1989, the ranking by poverty rate from highest to lowest was Guizhou, Henan, Hubei, Guangxi, Liaoning, Hunan, Shangdong and Jiangsu. In 2015, the order changed to Henan, Guizhou, Shangdong, Guangxi, Hunan, Heilongjiang, Hubei, Liaoning and Jiangsu. The ranking by poverty risk followed the same order as the poverty rate. In 2015, the poverty risk in Henan reached 1.82, which 
means that $1 \%$ of the population in Henan could explain $1.82 \%$ of rural poverty in China and implies that the rural population of Henan Province was very vulnerable to poverty. However, this ranking is quite different from China's official measurement, where Guizhou had the highest poverty rate in 2015, followed by Guangxi, Hunan, Henan, Hubei, Heinongjiang, Liaoning, Shangdong and Jiangsu.

Second, we consider the characteristics of the household head. Households of minority nationality had a higher poverty rate than the Han nationality in all periods, but the difference decreased over time. This is because most of China's minority populations live in western provinces, which are along China's land border and have backward economic growth. Hence, the poverty risk for minorities is also greater than 1, and a given proportion of the minority population will explain more of the poverty in China than the same proportion of Han nationality. However, the poverty risk of minorities is decreasing, and that of the Han nationality is increasing.

Before 2000, households with male heads had a higher poverty rate than households with female heads, and their poverty risk values were slightly higher than 1 . However, after 2000, the households whose heads were female had a higher poverty rate, and their poverty risk increased to a much higher value, with 1.40 and 1.28 in 2011 and 2015, respectively. Therefore, as the increasing vulnerability of modern Chinese families, households with female heads became much more vulnerable after 2011, and poor households may be targeted by the gender of the household head in the recent phase.

The occupation of the household head is another very important characteristic for targeting poverty. The Table 4 shows that the households whose head's occupation was farming have a much higher poverty rate than off-farm households in all periods. In 1989, farming households had a high poverty rate, reaching $70.47 \%$, but among off-farm households, the poverty rate was $35.27 \%$. Even in 2015 , the poverty rates were $14.24 \%$ to $7.78 \%$ for onfarm households and off-farm households. The poverty risks were greater than 1 for farmer in all years and increased from 1.16 in 1989 to 1.36 in 2015. For off-farm households, the poverty risk fluctuated around 0.5 ; while it reached 0.74 in 2015 , this value is still far smaller than that of on-farm households.

The marital status of the household head also has some effect on a household's development. Households whose head never married have the highest likelihood of being poor; their poverty rates are always greater than $30 \%$, and their poverty risks are greater than 2 after 2011,with 2.28 and 2.05 in 2011 and 2015, respectively. This means that the poverty of households whose head never married can explain 2 times more of the rural poverty in China than their population share. For some of the years, the second highest values by marital status are households whose head is widowed; from 1993 to 2011, households whose head is divorced have a higher poverty risk, but in 2015 , the poverty risk of divorced households declines to 0.73 . An intact family is very important to the development of household members and is highly correlated with the poverty status of the household.

With the increasing trend of population aging and cost of raising children, the dependency burden is becoming increasingly important in China. We find that, as the number of children and elderly dependents increases, the poverty headcount ratio and poverty risk are increasing. In 2015, the poverty risks are 0.96 for households with zero children and 1.42 for households with 2 children. In addition, the poverty risk is 0.89 for households with zero elderly members and 1.29 for households with 2 elderly members. The number of children in the household has a greater impact than the number of elderly household members. 
Table 5 Contributions of growth, redistribution and poverty line to poverty reduction (\%)

\begin{tabular}{|c|c|c|c|c|c|c|}
\hline & & & Total Change & Growth effect & Distributional effect & Poverty line \\
\hline \multirow{6}{*}{ 1989-1993 } & \multirow[t]{3}{*}{ Rural } & FGT0 & -5.45 & -18.15 & 2.41 & 10.29 \\
\hline & & FGT1 & -4.76 & -11.52 & 0.35 & 6.42 \\
\hline & & FGT2 & -4.23 & -7.81 & -0.76 & 4.34 \\
\hline & \multirow[t]{3}{*}{ Urban } & FGT0 & 3.16 & -21.63 & 6.89 & 17.90 \\
\hline & & FGT1 & 3.47 & -8.59 & 5.70 & 6.37 \\
\hline & & FGT2 & 2.48 & -4.59 & 3.75 & 3.31 \\
\hline \multirow[t]{6}{*}{ 1993-2000 } & \multirow[t]{3}{*}{ Rural } & FGT0 & -19.25 & -36.78 & 3.93 & 13.60 \\
\hline & & FGT1 & -8.91 & -20.76 & 0.04 & 11.80 \\
\hline & & FGT2 & -5.45 & -13.69 & 0.19 & 8.05 \\
\hline & \multirow[t]{3}{*}{ Urban } & FGT0 & -16.69 & -35.17 & 9.82 & 8.65 \\
\hline & & FGT1 & -4.83 & -15.14 & 2.38 & 7.93 \\
\hline & & FGT2 & -.170 & -8.84 & 2.28 & 4.86 \\
\hline \multirow[t]{6}{*}{ 2000-2011 } & \multirow[t]{3}{*}{ Rural } & FGT0 & -20.53 & -32.52 & 3.24 & 8.75 \\
\hline & & FGT1 & -6.97 & -15.11 & 3.78 & 4.36 \\
\hline & & FGT2 & 40.60 & 17.26 & 35.41 & -12.07 \\
\hline & \multirow[t]{3}{*}{ Urban } & FGT0 & -8.11 & -15.92 & 4.16 & 3.65 \\
\hline & & FGT1 & 1.83 & -5.90 & 5.14 & 2.59 \\
\hline & & FGT2 & 143.89 & 64.09 & 88.10 & -8.30 \\
\hline \multirow[t]{6}{*}{ 2011-2015 } & \multirow[t]{3}{*}{ Rural } & FGT0 & 0.95 & -5.33 & 5.19 & 1.09 \\
\hline & & FGT1 & 3.68 & -1.67 & 5.04 & 0.31 \\
\hline & & FGT2 & 51.49 & 51.91 & 9.25 & -9.67 \\
\hline & \multirow[t]{3}{*}{ Urban } & FGT0 & -2.47 & -2.22 & -1.18 & 0.93 \\
\hline & & FGT1 & -4.87 & -0.10 & -4.83 & 0.06 \\
\hline & & FGT2 & -144.93 & 107.45 & -236.24 & -16.14 \\
\hline
\end{tabular}

Foster-Greer-Thorbecke (FGT) class of poverty measures: FGT0 Headcount ratio, FGT1 poverty gap, and FGT2 Squared poverty gap

\subsubsection{The Shapley Decomposition of Poverty Dynamics}

3.5.3.1 Three-Factor Decomposition of the Poverty Headcount Ratio The results of the three-way poverty decomposition of the 4 periods are reported in Table 5. Considered China's rural areas first, poverty according to the three measures mainly declined in 1993-2000 and 2000-2011, and the rural poverty rate declined by $19.25 \%$ from 1993-2000 and by $20.53 \%$ from $2000-2011$. In the period $1989-1993$, rural poverty declined by $5.45 \%$, and in the period 2011-2015, the poverty rate increased by $0.95 \%$. However, there was little difference from the outcome with the squared poverty gap. After 2000, the squared poverty gap increased, and from 2000-2011 to 2011-2015, the squared poverty gap increased by 40.60 and $51.49 .^{7}$ These changes imply that the inequality among the poor was increasing over time; although many of the poor left poverty, the status of extreme poverty deteriorated.

\footnotetext{
7 Considering the FGT index formulas, we know that the FGT2 index is always less than the corresponding FGT1 value, which in turn is less than the FGT0 index. However, in our paper, poverty is measured by household net income, which has some negative values and will make the values of FGT1 and FGT2 larger than FGT0.
} 
From the Shapley decomposition, we find that real income growth has the main positive effect on poverty reduction in all periods.

The increase in the poverty line, which indicates the increase in the cost of living or inflation, mainly has a negative effect on poverty reduction. The increase in inequality is harmful to poverty reduction, and this adverse distributional effect becomes larger over time. Before 2011, the distributional effect was smaller than the growth effect and poverty line. From 1989-1993, the total change was $-5.45 \%$, where the effect of economic growth reduced poverty by $18.15 \%$, the increase in the poverty line raised poverty by $10.29 \%$, and inequality increased poverty by $2.41 \%$. From 1993 to 2000 and from 2000 to 2011 , the effects of growth, the poverty line and inequality were $36.78 \%, 13.60 \%$ and $3.93 \%$ and $32.52 \%, 8.75 \%$ and $3.24 \%$, respectively. After 2011 , the effect of growth was also very significant, but the distributional effect eliminated this positive effect. Combined with the effect of increasing cost of living, rural poverty finally increased by $0.95 \%$, where the growth effect was $-5.33 \%$, but the distributional effect was also very large, reaching $5.19 \%$. Although many studies have stated that the poverty reduction effect of economic growth in China is decreasing, we think that economic growth still has a large effect on poverty reduction in China and will still play an important role in poverty reduction in the future. However, the slowdown of economic growth after 2011 increases the difficulty of China's poverty reduction. The transformation of economic growth will be a very important task for China's government, and making growth more beneficial to the poor will be one important way to solve poverty and inequality.

Considering the Shapley decomposition of FGT1 and FGT2 for rural poverty in Table 5, we can obtain similar conclusions. Considering FGT2, from 2000, the growth effect offered little benefit to the extremely poor, so the FGT2 increased by $40.60 \%$, mainly due to the growth effect (17.26\%) and distributional effect (35.41\%). In the period 2011-2015, the distributional effect did not have a positive impact on poverty reduction and became the dominant effect. Moreover, even the growth effect became harmful to poverty reduction. All of these findings imply that not only has the income gap between the rich and the poor become increasingly larger, but the inequality among the poor population has also become very serious, especially in recent years. The increase in inequality also means that China will face a great challenge in reducing poverty according to the new poverty standard after 2020 , even though absolute poverty according to the current poverty standard may have been eliminated by 2020 . Therefore, the poverty reduction policy at the present stage must follow the principle of being more beneficial to the poor population, especially to those in extreme poverty. Then, it will be possible to accomplish the goal of eradicating rural absolute poverty according to the current poverty standard in 2020 and to assist the future poor population under the new poverty standard after 2020.

We next consider urban poverty, which was ignored by the government for most of the period. Economic growth also has the main effect on China's urban poverty reduction; the distributional effect and the increase in living cost work together in reverse, which increases urban poverty, especially in the early years, and their effect is very large. In the period $1989-1993$, although economic growth reduced the urban poverty rate by $21.63 \%$, urban poverty increased by $3.16 \%$ in total because of the increased inequality and living cost. FGT1 and FGT2 present the same conclusion. In the periods 1993-2000 and 2000-2011, although inequality and living costs still had large negative impacts on poverty reduction, rapid economic growth eliminated these negative effects, reducing urban poverty on a large scale. All these mean that urban poverty is much more vulnerable with macroeconomic fluctuation. 


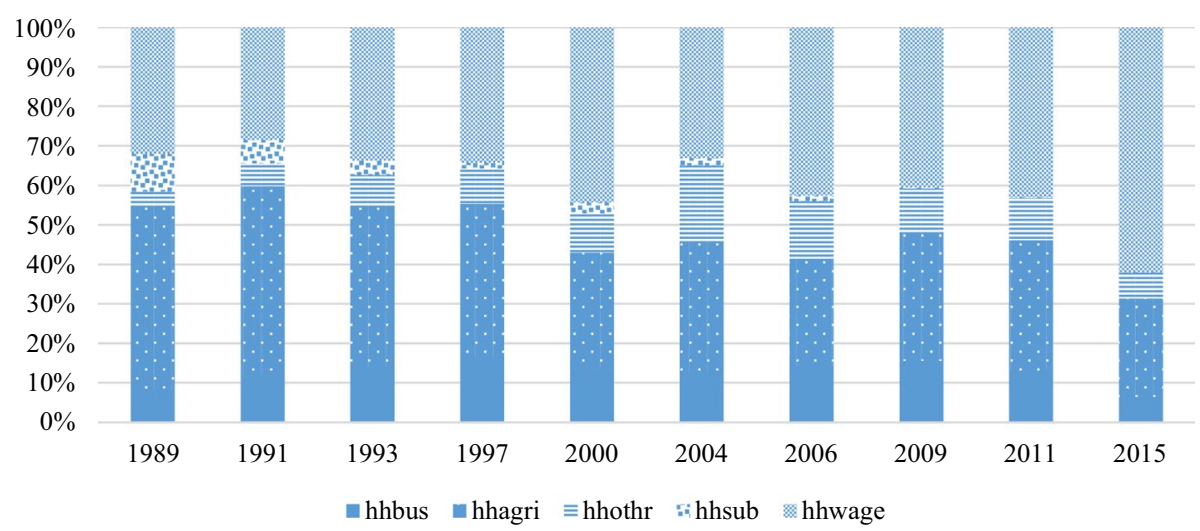

Fig. 6 Dynamic change of China's rural income composition. Note: hhbus is household income from business, hhagri is household agricultural income, hhothr is other income sources, hhsub is household income from subsidy, and hhwage is the household wage income

3.5.3.2 Decomposition by Income Sources In the CHNS, the sources of income are home gardening, farming, raising livestock/poultry, fishing, small handicraft and small commercial household business, wages and retirement wages, and other sources, including subsidies, welfare funds, money from children or parents (non-household member), money from friends or other relatives, and gifts from children or parents. In the calculation, we merged the income from gardening, farming, raising livestock and fishing into one new income category, agricultural income, and classified retirement wages as wages. Thus, there are five categories of income: household business income (hhbus), household agricultural income (hhagri), household subsidy (hhsub), household wage income (hhwage) and household other sources of income(hhothr). Household subsidies comprise policy subsidies, including one-child subsidies, gas or fuel subsidies, coal subsidies and electricity subsidies, which mainly existed in the early periods. Other income sources have a transfer role.

First, Fig. 6 shows the dynamic change in rural income composition among the poor. In 1989, the main income source for the rural population is household agricultural income, which accounts for $46.53 \%$ of total household income; next, wages account for $31.97 \%$, subsidy for $9.53 \%$, business income for $7.92 \%$ and other income for $4.02 \%$. Over time, household agricultural income declined from $46.53 \%$ in 1989 to $24.98 \%$ in 2015 but still accounted for a large proportion. With the large rural-urban population flow and accelerated urbanization in China, most of rural labor forces went to work in cities, wages became dominant in household income, increasing from $31.97 \%$ in 1989 to $61.96 \%$ in 2015 . Rural household business income increased from $7.92 \%$ in 1989 to $16.46 \%$ in 1997, then declined to and fluctuated around $6.41 \%$ in 2015 . Subsidy income declined from $9.53 \%$ in 1989 to $0.18 \%$ in 2015 , and other income increased from $4.02 \%$ to $19.62 \%$ in 2004 and then declined to $6.47 \%$ in 2015 .

Second, for urban residents, most of their income was from job wages, which account for a large share of their income in all periods, increasing from $55.11 \%$ in 1989 to $88.98 \%$ in 2015. In 1989, the proportions of wages, business, agricultural, subsidy and other income sources were $55.11 \%, 6.39 \%, 4.21 \%, 30.77 \%$ and $3.51 \%$, respectively. Then, in 2005, the main income sources for urban residents were wages, business and other income accounted for an additional $10 \%$ of the total income. In these 20 years, business income 
Table 6 Contribution of income sources to poverty reduction (\%)

\begin{tabular}{|c|c|c|c|c|c|c|c|c|}
\hline & & & Total change & hhbus & hhagri & hhsub & hhwage & hhothr \\
\hline \multirow[t]{8}{*}{ 1989-1993 } & \multirow[t]{4}{*}{ Rural } & FGT0 & -5.451 & -2.421 & -1.837 & 4.234 & -4.392 & -1.035 \\
\hline & & FGT1 & -4.761 & -1.313 & -3.122 & 2.995 & -1.760 & -1.560 \\
\hline & & FGT2 & -4.232 & -0.899 & -3.052 & 2.262 & -0.922 & -1.621 \\
\hline & & Gini & 0.002 & 0.006 & -0.015 & 0.005 & 0.013 & -0.007 \\
\hline & \multirow[t]{4}{*}{ Urban } & FGT0 & 3.163 & -0.476 & -0.273 & 10.331 & -7.937 & 1.1518 \\
\hline & & FGT1 & 3.474 & -0.614 & 0.779 & 5.914 & -2.890 & 0.285 \\
\hline & & FGT2 & 2.479 & -0.794 & 0.941 & 4.128 & -1.577 & -0.220 \\
\hline & & Gini & 0.066 & 0.016 & 0.008 & 0.036 & -0.000 & 0.005 \\
\hline \multirow[t]{8}{*}{ 1993-2000 } & \multirow[t]{4}{*}{ Rural } & FGT0 & -19.255 & -1.586 & -6.733 & 3.446 & -12.265 & -2.118 \\
\hline & & FGT1 & -8.910 & 0.089 & -4.167 & 2.065 & -4.562 & -2.335 \\
\hline & & FGT2 & -5.449 & 0.654 & -2.730 & 1.390 & -2.322 & -2.440 \\
\hline & & Gini & 0.022 & 0.008 & -0.021 & 0.010 & 0.035 & -0.011 \\
\hline & \multirow[t]{4}{*}{ Urban } & FGT0 & -16.692 & -1.520 & 0.208 & 3.663 & -17.972 & -1.071 \\
\hline & & FGT1 & -4.832 & -0.237 & 1.751 & 2.123 & -7.224 & -1.244 \\
\hline & & FGT2 & -1.696 & 0.012 & 2.071 & 1.494 & -3.988 & -1.285 \\
\hline & & Gini & 0.030 & 0.002 & 0.004 & 0.031 & 0.002 & -0.008 \\
\hline \multirow[t]{8}{*}{ 2000-2011 } & \multirow[t]{4}{*}{ Rural } & FGT0 & -20.532 & 1.017 & -12.618 & 1.146 & -6.152 & -3.924 \\
\hline & & FGT1 & -6.966 & 5.298 & -6.068 & 0.103 & -2.625 & -3.673 \\
\hline & & FGT2 & 40.602 & 176.503 & -36.925 & -30.253 & -33.747 & -34.975 \\
\hline & & Gini & 0.039 & 0.065 & -0.036 & -0.003 & 0.017 & -0.004 \\
\hline & \multirow[t]{4}{*}{ Urban } & FGT0 & -8.107 & 1.020 & -1.934 & 1.659 & -7.932 & -0.919 \\
\hline & & FGT1 & 1.832 & 4.094 & 0.201 & 1.229 & -2.674 & -1.019 \\
\hline & & FGT2 & 143.891 & 100.554 & 14.345 & 14.972 & 3.129 & 10.891 \\
\hline & & Gini & 0.012 & 0.057 & -0.008 & -0.005 & -0.035 & 0.002 \\
\hline \multirow[t]{8}{*}{ 2011-2015 } & \multirow[t]{4}{*}{ Rural } & FGT0 & 0.950 & 1.456 & 1.922 & 0.320 & -4.857 & 2.108 \\
\hline & & FGT1 & 3.682 & -0.937 & 4.092 & 0.782 & -2.909 & 2.655 \\
\hline & & FGT2 & 51.491 & -138.99 & 116.66 & 24.007 & 22.473 & 27.340 \\
\hline & & Gini & 0.066 & 0.000 & 0.035 & 0.002 & 0.014 & 0.015 \\
\hline & \multirow[t]{4}{*}{ Urban } & FGT0 & -2.471 & 0.866 & 0.946 & -0.490 & -4.424 & 0.631 \\
\hline & & FGT1 & -4.873 & -1.737 & 0.975 & -0.990 & -3.845 & 0.724 \\
\hline & & FGT2 & -144.93 & -131.00 & 30.687 & -19.599 & -10.164 & -14.854 \\
\hline & & Gini & 0.039 & 0.002 & 0.015 & -0.005 & 0.018 & 0.009 \\
\hline
\end{tabular}

increased from $6.39 \%$ in 1989 to $14.535 \%$ in 1997 , then declined to $4.95 \%$ in 2015 , following the same dynamics as rural business income, and the turning point of other income sources is the year 2004 .

In Table 6, we decompose China's poverty dynamics by income source. First, we examine rural poverty in China. In different periods, each income source plays a different role in poverty, and wages play an important role in rural poverty reduction. In 1989-1993, the rural poverty rate declined by $5.45 \%$, and wages, household business and household agricultural income contributed this decline by $4.39 \%, 2.42 \%$, and $1.837 \%$, but the household subsidy income increased rural poverty by $4.234 \%$. Different from the FGT0 measure, in 1989-1993, the greatest declines in rural poverty according to the FGT1 and FGT2 
measures are from household agricultural income, followed by wages and household business income. As found for the FGT0 measure, the income from household subsidy had a negative effect on poverty reduction. The differences among the three measures imply that, although the wage increase was the main force lifting most of the rural population out of poverty, the increase in agricultural income was very important to the reduction of extreme poverty in the early period. These values are similar for the period from 1993 to 2000. In this period, China's rural poverty rate declined by $19.26 \%$, and the wage increase contributed to the decline by $12.27 \%$. However, for the FGT1 and FGT2 measures, agricultural income contributed the most to the poverty decline, and household subsidy still represented the main negative factor.

In the period 2000-2011, agricultural income accounted for the greatest decline in rural poverty; in this period, the poverty rate declined by $20.53 \%$, and the increase in agricultural income reduced by $12.62 \%$. Then, wages and other income, business income and subsidy had negative effects on poverty reduction. In this period, China conducted a series of pro-agricultural policies. In 2004, China began to implement agricultural tax reduction and exemption, and simultaneously provided agricultural subsidies to improve peasants' motivation for planting. Since January 1st, 2006, China has abolished the agricultural tax. All these values are similar to those for the FGT1 measures. The FGT2 measures differ slightly from FGT0 and FGT1; because of the great loss of business income, FGT2 increased in the period 2000-2011, but agricultural income, subsidy, wages and other income had some positive effects on poverty reduction.

In the period 2011-2015, the effects of these income sources were completely different from the effects in other periods. The positive effect of agricultural income on poverty reduction disappeared and turned negative for all poverty measures. All other income sources also turned to present negative effects on poverty reduction for the FGT0 measure, except for wages. Wages again became the dominant factor of poverty reduction, and their increase decreased the poverty rate by $4.86 \%$ from 2011 to 2015 . However, the effects were different for FGT1 and FGT2; the improved business income reduced poverty, and other income sources were no longer beneficial for poverty reduction. The difference among these measures shows that the wages from the labor market have become important for China's rural poverty reduction but have not reduced rural extreme poverty. Perhaps because of a lack of capability, those in extreme poverty in rural areas cannot enter the labor market. This also implies that the poverty reduction policy must be differentiated among poor groups in rural China. Rapid economic growth is better for those who have labor capability, but for those in extreme poverty, the improvement in the poverty relief system may be more effective, and the government can provide transfers or training to these groups.

Since wages are the main income source in urban China and China has experienced rapid economic growth since the reform and opening up after 1978, wages have contributed to most of the urban poverty reduction in all periods and for all poverty measures. Household business income had some positive effect on poverty reduction in the periods 1989-2000 and 2011-2015, but in 2000-2011, it had a negative effect on poverty reduction in urban China. Household subsidy was unfavorable to urban poverty reduction before 2011, especially in 1989-1993, and the large adverse effect led the poverty in urban China to increase in this period. This adverse effect declined from 2011-2015, when household subsidy became favorable to urban China's poverty reduction.

In this table, we also decompose inequality by income source, using the Gini coefficient. During all four periods, the Gini coefficient increases for both rural and urban China. This means that inequality in China is increasing after the reform, and this 
Table 7 The waves of poverty

\begin{tabular}{lllllllllr}
\hline Poverty waves & 0 & 1 & 2 & 3 & 4 & 5 & 6 & 7 and above & Total \\
\hline National (N) & 3517 & 1423 & 836 & 635 & 485 & 366 & 264 & 229 & 7755 \\
Percent (\%) & 44.35 & 18.35 & 10.78 & 8.19 & 6.25 & 4.72 & 3.41 & 2.95 & 100 \\
Rural (N) & 1439 & 852 & 589 & 492 & 387 & 320 & 229 & 201 & 4509 \\
Percent (\%) & 31.91 & 18.90 & 13.06 & 10.91 & 8.58 & 7.1 & 5.08 & 4.46 & 100 \\
Urban (N) & 2078 & 571 & 247 & 143 & 98 & 46 & 35 & 28 & 3246 \\
Percent (\%) & 64.02 & 17.59 & 7.61 & 4.41 & 3.02 & 1.42 & 1.08 & 0.86 & 100 \\
\hline
\end{tabular}

increase exists in both rural and urban areas. In rural areas, the increasing rate of inequality was growing faster, and the Gini coefficient increased by 0.002 in the period 1989-1993, 0.022 in 1993-2000, and 0.039 in 2000-2011 and then reached a high value of 0.066 in the final period. Poverty increased from 2011 to 2015, as the adverse effect of inequality outweighed the growth effect on poverty. However, in urban areas, the Gini coefficient increased by 0.066 in the period 1989 to 1993 , and then the speed of increase was reduced: the coefficient increased by 0.030 from 1993 to 2000 and by 0.012 from 2000 to 2011, while in period 2011-2015, the speed of increase became faster again, rising to 0.039 .

However, the sources of the increasing Gini coefficient are different for rural and urban areas in these four periods. In rural China, the increase in the Gini coefficient was mainly from wage and household business income; in the periods 1989-1993 and 1993-2000, wages were the main source of increasing rural inequality. Household business income from 2000-2011 and agricultural income from 2011-2015 became the dominant factors of the increase in the rural Gini coefficient. Other factors contributed to reducing inequality. From 1989 to 2011, agricultural and other income sources were beneficial to inequality reduction, especially agricultural income, whose favorable effect was very strong and increasing. The Gini coefficient was reduced by 0.015 from 1989 to 1993 , by 0.021 from 1993-2000 and by 0.036 in the period 2000-2011, perhaps due mainly to the benefits from few agricultural reforms in rural China. However, in the period 2011-2015, all kinds of income were reasons for the increase in the Gini coefficient in rural areas. For urban China, in the periods 1989-1993 and 1993-2000, most of the high inequality came from the household subsidy, and only other household income reduced a little of this inequality. However, after 2000, the household subsidy became favorable to reducing poverty. In the period 2000-2011, urban inequality mainly came from household business income, and the positive effects of household agricultural income, subsidy and especially wages improved the urban distributional problem. In the period 2011-2015, because of the negative effects of wages and agricultural income, together with the small favorable effect of household subsidies, the speed of urban inequality increased.

3.5.3.3 Poverty Transition Ten rounds of the CHNS have been conducted, spanning 26 years. This long period allows us to trace the changes in individual poverty. In Table 7 , we calculate the persistence of poverty. At the national level, $44.35 \%$ of households are never poor in all waves, while in rural China, $31.91 \%$ of households are never poor, and $64.02 \%$ are never poor in urban China. Then, $55.65 \%$ of households are in poverty for at least some of the years covered, of which $2.95 \%$ are in poverty for at least 7 survey 


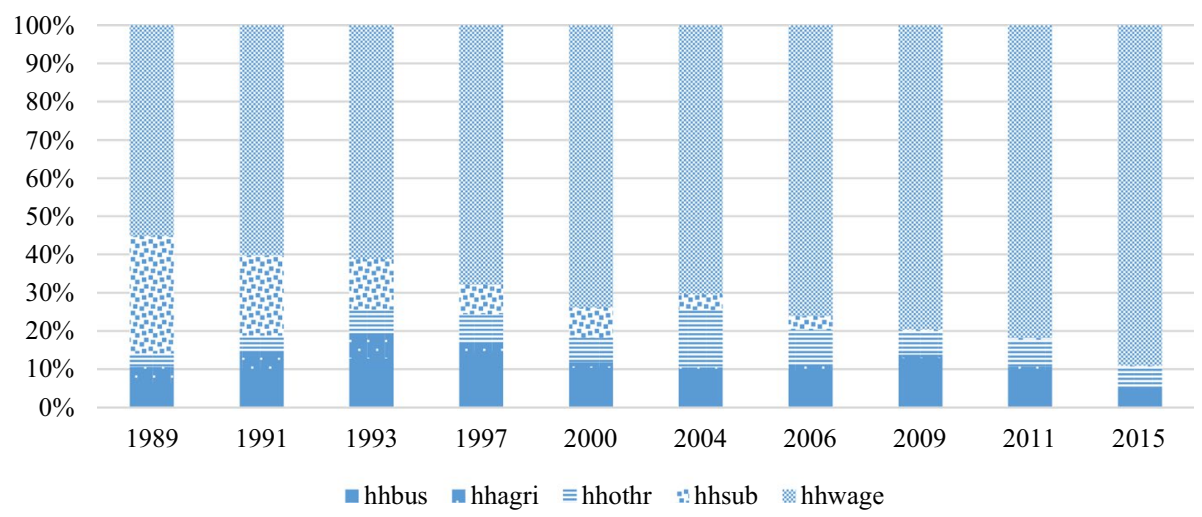

Fig. 7 Dynamic change of China's urban income composition. Note: hhbus is household income from business, hhagri is household agricultural income, hhothr is other income sources, hhsub is household income from subsidy, and hhwage is the household wage income

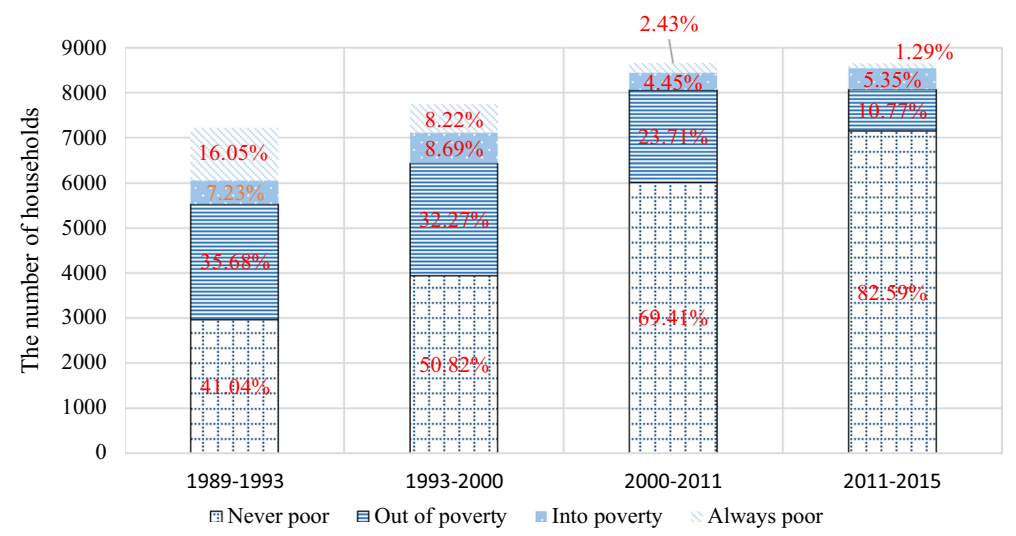

Fig. 8 The transition of rural poverty in the four periods

rounds. This is a long time to be in poverty, and we can consider these households to suffer from extreme and persistent poverty. As the Table 7 shows, these households in persistent poverty were mainly located in rural areas; the headcount ratio is $4.46 \%$ for rural persistent poverty, and only $0.86 \%$ of urban households are in persistent poverty. (Fig. 7).

We also considered four kinds of people in these four periods: those who are poor both at the beginning and the end of the period (persistent poverty); those who are poor at the beginning of the period but not at the end of the period (went out of poverty); those who are not poor at the beginning but become poor at the end (went into poverty); and those who are not poor at the beginning or the end. The Fig. 8 shows that China has achieved a great performance in poverty reduction; the proportion of households that were never poor in a given period increased from $41.04 \%$ in 1989-1993 to $82.59 \%$ in 2011-2015, and the proportion of households that were in poverty in both years declined from $16.05 \%$ to $1.29 \%$. The trends in the figures also imply that poverty reduction becomes increasingly difficult; the proportion of households that went out of poverty declined from $35.68 \%$ to $10.77 \%$, and the proportion of households that entered 
into poverty declined gently with some fluctuations. In the period 1989-1993, 7.23\% of households went into poverty. From 1993 to 2000, this proportion increased to $8.69 \%$; from 2000 to 2010 , the proportion decreased greatly to $4.45 \%$; and it increased slightly to $5.35 \%$ from 2011 to 2015 .

The fluctuations in the poverty trend are due to two factors: negative shocks from natural disasters, macroeconomic fluctuations and family misfortune, and family capabilities, such as assets owned, education, health and job. First, it is not easy to address natural disasters, and family misfortune occurs in each period for every person. In these 26 years, there are some important negative shocks from macroeconomic fluctuations, such as high inflation between 1993 and 1995, the Asian financial crisis between 1997 and 1999, and the American subprime debt crisis in 2008. Some natural disasters also occurred in this period, such as the 1998 flood in the Yangtze River basin, snow disaster in early 2008 and Wenchuan earthquake on May 12th, 2008. And in early 2020, the novel coronavirus(COVID-19) outbroke in China, and the later flood. These negative shocks were not beneficial for poverty reduction and made the people be much more vulnerable, even made them go into poverty.

In Table 8, we use a multi-nominal logit regression to analyze the dynamics of poverty. We consider two kinds of people who went into poverty with different base groups. The first group is never poor in a given period, and the second group is poor at the beginning of the period but not at the end. The second type, in turn, can also be interpreted as people who went out of poverty. As shown in the table, the characteristics of the household head were not very important to the dynamics of poverty, especially for the people who went out of poverty. As the age of household head increased, the possibility of poverty first declined and then increased, and the turning point was between 40 and 50 years. The gender, marital status, ethnicity, and education of the household head were not main characteristics of the poverty transition. This is different from the conclusions of traditional studies on poverty characteristics, which find that households whose head is minority, female and divorced have a higher possibility of being poor. Occupation has a significant effect on poverty, especially for the people who fall into poverty; farmers are much more likely to fall into poverty and harder to escape from poverty, but after 2000, although farmers still more easily fall into poverty, they face less difficulty in escaping from it.

Considering household characteristics, having more children in the household is beneficial for escaping from poverty during the period 1993 to 2011 . Having more elderly family members is a non-significant factor in the poverty transition in all periods. Larger household size increases the likelihood of falling into poverty and has adverse effects on escaping from poverty. The most important reason for the increase in household size is the newborns which will increase the burden, as well as the death of elderly household members will decrease the burden. In addition, the increase in the number of employed persons will make it easier for a household to escape from poverty and more difficult to fall into poverty.

In Table 8, we consider two other important variables: income growth and standard deviations of community income, which can be used to analyze how economic growth and inequality affect the poverty transition. As the regression outcome shows, the increase in income was always the main impetus preventing households from falling into poverty and pushing households out of poverty, and these effects were significant, except for the effect on escaping poverty in the period 2011-2015. In 2011-2015, China's economic growth entered an adjustment period, and it slowed down from 2012. The inequality effect was different in the four periods considered. Inequality had a negative effect on escaping poverty and made households more likely to fall into poverty before 2000. After 2000, inequality 


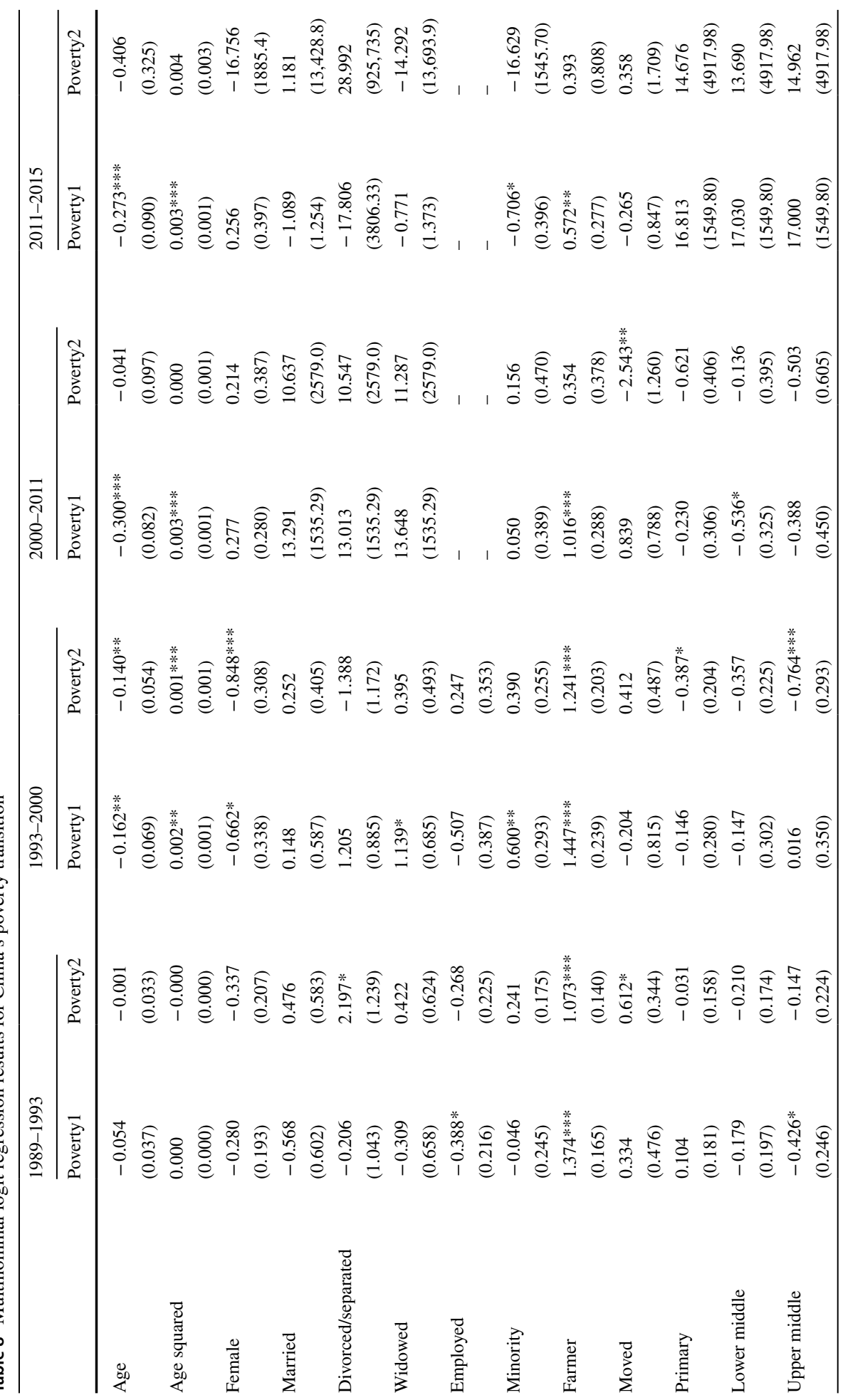




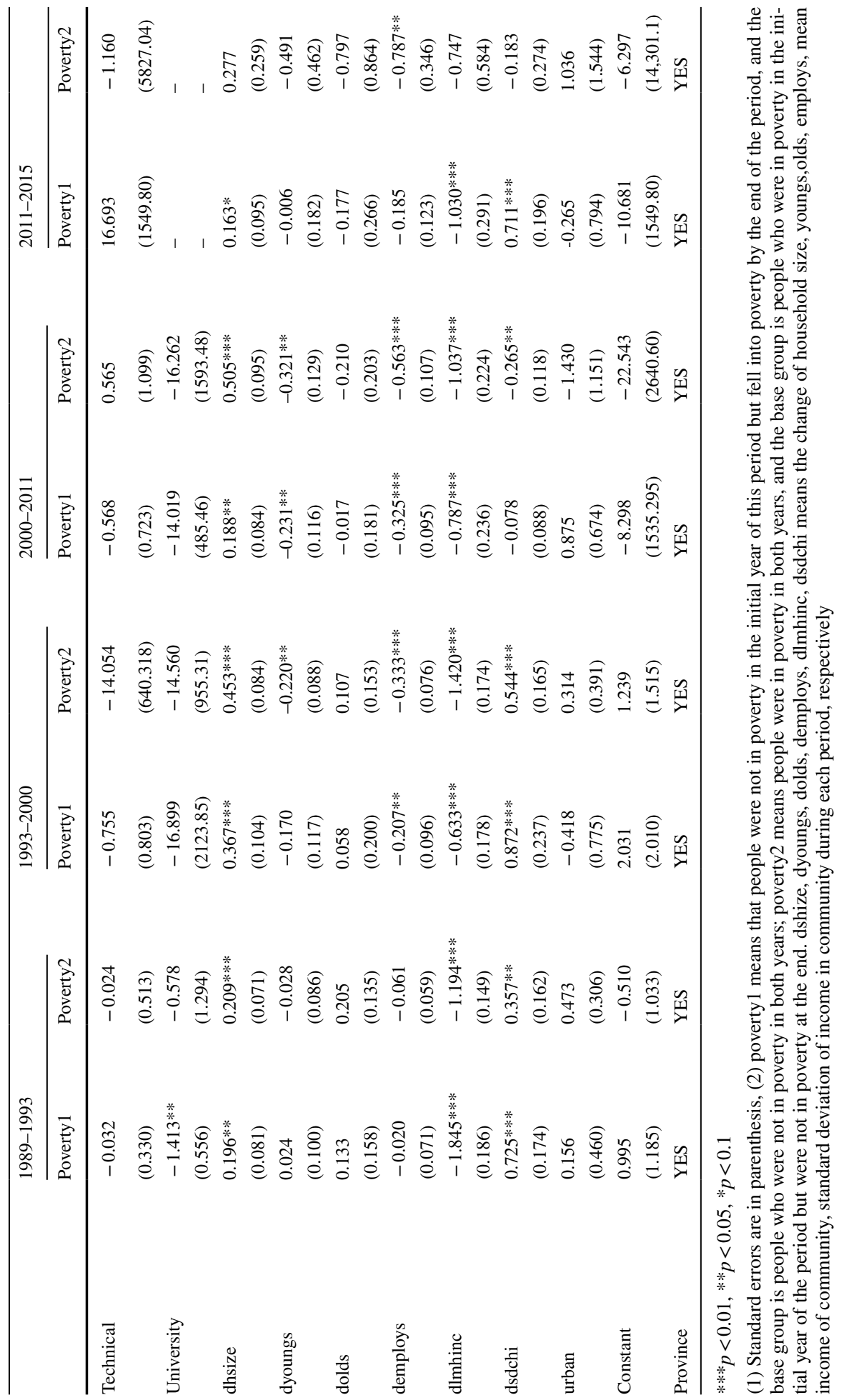


had a positive effect enabling households to escape poverty, but it was still an important factor contributing to household poverty. These results imply that inequality can help eliminate poverty near the poverty line, but it can also increase the problem of extreme poverty for households who do not benefit from growth and face more persistent poverty.

\section{Conclusions}

China is entering a new stage for poverty alleviation. What is next plan of poverty identification and poverty reduction is one important issue for future research. The analysis of poverty reduction in the past 40 years could provide a good reference to address this issue. Hence, in this paper, we used CHNS data from 1989 to 2015 to analyze the dynamics of poverty in China according to the evolution of poverty reduction policies. We found that the characteristics of poverty population become externalization, the households with female head, living in the rural areas, west provinces and so on, gradually become the main part of poverty populations. Although the growth effect becomes weaker, it still provides the most contribution to poverty reduction. The adverse effect of inequality becomes stronger, and exceeds the growth effect. The macroeconomic fluctuation is not beneficial to poverty reduction, especially for the urban population. The series of agricultural reforms conducted in the period 2000-2010 made the agricultural income play an important role in rural poverty reduction, but as the rural-urban flow, wage becomes the main sources of income for both rural and urban households, and increases the inequality in rural areas which in not beneficial for the poor who escape poverty reluctantly and increases their vulnerability.

Hence, first of all, economic growth will be still the most important factors to China's future poverty reduction. However, as the shock of financial crisis happened in 2008, China's economy went into a special period officially called "the New Normal", and the national growth rate fell from $9.6 \%$ in 2011 to $7.9 \%$ in 2012 and then continued to decrease to $6.1 \%$ in 2019 . COVID-19, flood and trade friction also brought great challenge to China's future economic growth, which are not beneficial to poverty reduction. It implies that China needs to implement series of new reforms furtherly, including land, agricultural, registration system, healthcare, education, social security, housing and so on, which can promote rural-urban flow, improve the capability, and finally re-activate the "demographic dividend", provide the new impetus for China's future growth.

Second, the adjustment of income distribution to reduce inequality will be the most important job in China's development, especially the distribution of labor income, which has become the major income sources both for the rural and urban area. Chinese government has been emphasizing the quality of future growth, in which, an important aspect is how to make growth more beneficial to the poor. But China's inequality is increasing which is not beneficial to poverty reduction, especially in the identification system of relative poverty. Rising income inequality weakened the growth effect on poverty reduction, made people more vulnerable to poverty. What's more, China officially planned to use the relative poverty standard to identify the poor, which means increasing inequality will make China's future poverty problem be still a persistent challenge. The sources of inequality from urban-rural, gender, west-east will make those households with female head and higher dependency, in the rural areas, west provinces, be still the main targets for identification of China's poverty population in future poverty research and management. Regional balanced development will be very important in future growth and poverty reduction. 
Third, construction of an integrated rural-urban poverty alleviation system. With rapid urbanization and the rural-urban population flow, the urban poverty problem, which has been ignored in the journey of China's poverty alleviation, should be listed on the government agenda. According to our measurement, China's urban poverty was also very serious. Because of great difference of development between rural China and urban China, the construction of relatively integrated rural-urban poverty alleviation system should be considered and studied in the future. Wages gradually became the main income sources to reduce rural poverty and urban poverty, this could provide a breakthrough to build the integrated rural-urban system.

In rural areas, the series of agricultural reforms had significant effects on China's rural economic growth, poverty reduction and inequality, especially in the period 2000 to 2011 , government subsidies and elimination of agricultural tax made agricultural income become the main force to reduce poverty compared to all other types of income. But the rural poverty of education, health, drinking water, cooking fuel, et al., are still very high. If we would such as to take targeted to measure poverty and reduce poverty, income will be not enough in the future, it will be worth considering all aspects of household information and measuring poverty from a relatively multidimensional perspective.

The last, poverty vulnerability caused by negative shocks, including macroeconomic fluctuation, health and natural disasters, would be the most important sources for future poverty in China, especially the health shock. According to China's official statistics, poverty due to illness accounted for $44.1 \%$ of total rural poverty population in 2015 and kept above $42 \%$ since 2015 . COVID-19 and flood made many people return to poverty and deepened the inequality which furtherly made the poverty reduction become much more difficult in 2020. Hence, it is necessary to improve the individual capability, and promote the rural-urban unified resident insurance into national-wide network, improve the Minimum Living Standard Guarantee System, and build an integrated rural-urban social relief system. All these finally make China's poverty reduction become normalized and institutionalized.

Of course, our paper has found what should we do in future from the analysis on history of China's poverty alleviation, but how to do with these four aspects in detail need further research. It is a pity that the data after 2015 is not available. China's president Xi put forward the concept of "take targeted to measure poverty" in the end of 2013. Although our paper has included the period 2011-2015, it's not enough to acquire the total poverty reduction effect significantly. We will continue to improve the research when the data update lately.

Funding This work was supported by National Natural Science Foundation of China (Grant number: 72003143) and the Research Project in Humanities and Social Sciences by the Ministry of Education of China (Grant number:18YJA790021).

Data availability It can be provided if necessary.

Code availability It can be provided if necessary.

\section{Declarations}

Conflict of interest The authors declare that they have no conflict of interest. 


\section{References}

Adigun, G. T., Bamiro, O. M., \& Adedeji, I. A. (2015). Explaining poverty and inequality by income sources in rural nigeria. Journal of Humanities and Social Science, 20(3), 61-70.

Alkire, S., \& Fang, Y. (2019). Dynamics of multidimensional poverty and uni-dimensional income poverty: an evidence of stability analysis from china. Social Indicators Research, 142(1), 25-64.

Alkire, S. \& Foster J. (2007). Counting and Multidimensional poverty measurement, OPHI Working Paper 7,University of Oxford.

Alkire, S., \& Foster, J. (2011). Counting and multidimensional poverty measurement. Journal of Public Economics, 95(7-8), 476-487.

Azevedo, J. P., Nguyen, M. C., \& Sanfelice, V. (2012). ADECOMP: Stata module to estimate Shapley Decomposition by Components of a Welfare Measure, Statistical Software Components S457562. Boston College Department of Economics.

Azevedo, J. P., Sanfelice, V., \& Nguyen, M.C. (2012). Shapley Decomposition by Components of a Welfare Aggregate, MPRA Paper No. 85584.

Azevedo, J. P., Inchauste, G., Olivieri, S., Saavedra, J. \& Winkler, H. (2013). Is labor income responsible for poverty reduction? A decomposition approach, Policy Research Working Paper 6414. The World Bank.

Chen S., \& Ravallion, M. (2008). China is Poorer than we Thought, But No Less Successful in the Fight against Poverty, Policy Research Working Paper 4621, The World Bank.

Chen S., \& Ravallion, M. (2020). Reconciling the conflicting narratives on poverty in China, NBER Working Paper 28147.

Chen, J., Rong S., \& Song, M. (2021). Poverty vulnerability and poverty causes in rural china. Social Indicators Research, 153, 65-91. https://doi.org/10.1007/s11205-020-02481-x

Dat, G., \& Ravallion, M. (1992). Growth and redistribution components of changes in poverty measures: A decomposition with applications to brazil and india in the 1980s. Journal of Development Economics, 38(2), 275-296.

Deruso, M. and Spears, D.(2015). Neighborhood Sanitation and Infant Mortality, NBER working paper 21184.

Du, Y., Park, A., \& Wang, S. (2005). Migration and rural Poverty in China. Journal of Comparative Economics, 33(4), 688-709.

Duclos, J.-Y., Araar, A., \& Giles, J. (2010). Chronic and transient poverty: Measurement and estimation, with evidence from China. Journal of Development Economics, 91(2), 266-277.

Duflo, E., Greenstone, M., Guiteras R., \& Clasen, T (2015). Toilets can work:short and medium run health impacts of addressing complementaries and externalities in water and sanitation. Working Paper.

Fang, Y. \& Zou, W. (2014). Neighborhood effects and regional poverty traps in rural china. China \& World Economy, 22(1), 83-102.

Kong, F. (2018). The Historical Evolution and Its innovation of Poverty Alleviation Policy Since the Reform and Opeing-up: A study Centered on the CPC's NO. 1 Document, Contemporary China History Studies (In Chinese), (2): 111-120+128.

Foster, J., Greer, J., \& Thorbecke, E. (1984). A class of decomposable poverty measures. Econometrica, 52(3), 761-766.

Gao, Q., Zhai, F., \& Garfinkel, I. (2010). How does public assistance affect family expenditures? The Case of Urban China, World Development, 38(7), 989-1000.

Gao, Q., Zhai, F., Yang, S., \& Li, S. (2014). Does Welfare Enable Family Expenditures on Human Capital?Evidence from China. World Development, 64, 219-231.

Glauben, T., Herzfeld, T., Rozelle, S., \& Wang, X. (2012). Persistent poverty in rural china: Where. Why and How to Escape, World Development, 40(4), 784-795.

Goh, C., Luo, X., \& Zhu, N. (2009). Income growth, inequality and poverty reduction: A case study of eight provinces in China. China Economic Review, 20, 485-496.

Golan, J., Sicular, T., \& Umapathi, N. (2017). Unconditional cash transfers in China: Who benefits from the rrural minimum living standard guarantee (dibao) program. World Development, 93, 316-336.

Guo,Y., Zhou Y., and Liu, Y. (2019).Targeted poverty alleviation and its practices in rural China:A case study of Fuping County, Hebei Provinces, Journa of Rural Studies. https://doi.org/10.1016/j.jrurstud. 2019.01.007.

Household Survey Department of National Bureau of Statistics. (2000). Poverty monitoring report of rural China. China Statistics Press.

Jalan, J., \& Ravallion, M. (1998). Transient poverty in postreform rural china. Journal of Comparative Economics, 26, 338-357. 
Kolenikov, S., \& Shorrocks, A. (2005). A decomposition analysis of regional poverty in russia. Review of Development Economics, 9(1), 25-46.

Li, S. (2014). Poverty reduction and effects of Pro-poor Policies in Rural China. China \& World Economy, $22(2), 22-41$.

Li, H. \& Zhou, L. (2005). Political turnover and economic performance: The incentive role of personnel control in China. Journal of Public Economics, 89(9), 1743-1762.

Liao, C., et al. (2021). Targeted poverty alleviation through photovoltaic-based intervention: Rhetoric and reality in Qinghai. China, World Development, 137, 105-117.

Lin, J. Y. (1992). Rural reforms and agricultural growth in china. The American Economic Review, 82(1), 34-51.

Lu, X. (2015). Intergovernment transfers and local education provision-evaluating china's 8-7 national plan for poverty reduction. China Economic Review, 33, 200-211.

Meng, L. (2013). Evaluating China's poverty alleviation program: A regression discontinuity approach. Journal of Public Economics, 101, 1-11.

Montalvo, J. G., \& Ravallion, M. (2010). The pattern of growth and poverty reduction in China. Journal of Comparative Economics, 38(1), 2-16.

Park, A., \& Wang, S. (2010). Community-based development and poverty alleviation: An evaluation of China's poor village investment program. Journal of Public Economics, 94(9-10), 790-799.

Park, A., Wang, S., and Wu, G. (2002). Regional poverty targeting in China. Journal of Public Economics, $86(1), 123-153$.

Qin, C., \& Chong, T. L. (2018). Can poverty be alleviated in China? Review of Income and Wealth, 64(1), 192-212.

Rani, U., \& Furrer, M. (2016). Decomposin income inequality into factor income components. Evidence from selected G20 countries, ILO Research Paper NO. 15.

Ravallion, M. (2005). Inequality is bad for the poor. World Bank Policy Research Working Paper No. 3677.

Ravallion, M., \& Chen, S. (2007). China's (uneven) progress against poverty. Journal of Development Economics, 82(1), 1-42.

Shorrocks, A. F. (2013). Decomposition procedures for distributional analysis: A unified framework based on the Shapley value. Journal of Economic Inequality, 11(1), 99-126.

Toyin, A. G., \& Timothy, A. T. (2014). Economic grwoth, income redistribution and poverty reduction: Experiences from rural Nigeria. Asian Journal of Agricultural Extension, Economics \& Sociology, 3(6), 638-653.

Ward, P. S. (2016). Transient poverty, poverty dynamics, and vulnerability to poverty: An empirical analysis using a balanced panel from rural China. World Development, 78, 541-553.

Wang, S. (2007). Retrospect and prospect of China's rural poverty alleviation. Agricultural Outlook (in Chinese), 1, 6-8.

Wang S., Li Z., \& Ren Y. (2004).The 8-7 National Poverty Reduction Program in China-The National Strategy and Its Impact, Scaling Up Poverty Reduction: A Global Learning Process and Conference, Shanghai, May 25-27, 2004.

Wang H., Zhao, Q., et al. (2020). Poverty and subjective poverty in rural China. Social Indicators Research, 150, 219-242. https://doi.org/10.1007/s11205-020-02303-0

Weide, R., \& Milanovic, B. (2018). Inequality is bad for growth of the poor (But not for that of the rich). The World Bank Economic Review, 32(3), 507-530.

Westmore, B. (2018). Do government transfers reduce poverty in China? Micro Evidence from Five Regions, China Economic Review, 51, 59-69.

$\mathrm{Xu}, \mathrm{C} .(2011)$. The fundamental institutions of china's reforms and development. The Journal of Economic Literature, 49(4), 1076-1151.

Yao, S. (1999). Economic growth, income inequality and poverty in China under economic reforms. The Journal of Development Studies, 35(6), 104-130.

Zhang Y., \& Wan, G. (2006). The impact of growth and inequality on rural poverty in China. Journal of Comparative Economics, 34(4), 694-712.

Yu, J. (2013). Multidimensional poverty in china: Findings based on the CHNS. Social Indicators Research, 112(2), 315-336.

Zhang, J. (2012). The impact of water quality on health: Evindence form the drinking water infrastructure program in rural China. Journal of Health Economics, 31(1), 122-134.

Zhang, C., Xu, Q., Zhou, X., Zhang, X., \& Xie, Y. (2014). Are poverty rates underestimated in China? New Evidence from Four Recent Surveys, China Economic Review, 31, 410-425.

Zhang, J., \& Xu, L. (2016). The long-run effects of treated water on education: The rural drinking water program in China. Journal of Development Economics, 122, 1-15. 
Zhu, X. (2012). Understanding China's growth: Past, present, and future. The Journal of Economic Perspectives, 26(4), 103-124.

Publisher's Note Springer Nature remains neutral with regard to jurisdictional claims in published maps and institutional affiliations. 